\title{
Expanding Opportunities: A Framework for Gender and Socially-Inclusive Climate Resilient Agriculture
}

\author{
Sophia Huyer ${ }^{1 *}$, Elisabeth Simelton ${ }^{2}$, Nitya Chanana ${ }^{3}$, Annet Abenakyo Mulema ${ }^{4}$ and \\ Edwige Marty ${ }^{5}$
}

${ }^{1}$ CGIAR Program on Climate Change, Agriculture and Food Security, International Livestock Research Institute, Nairobi, Kenya, ${ }^{2}$ CGIAR Program on Climate Change, Agriculture and Food Security, World Agroforestry, Hanoi, Vietnam, ${ }^{3}$ CGIAR Research Program on Climate Change Agriculture and Food Security, The Alliance of Bioversity International and International Center for Tropical Agriculture, Palmira, Colombia, ${ }^{4}$ International Development Research Centre, Nairobi, Kenya,

${ }^{5}$ Sustainable Livestock Systems, International Livestock Research Institute, Nairobi, Kenya

Limiting global warming to the $2^{\circ} \mathrm{C}$ target that countries have committed to in the 2015 Paris Agreement, and reaching the Sustainable Development Goals by 2030, will require large-scale expansion of climate-resilient approaches in agriculture and food systems. In order to achieve the scale of change required, coordinated action is needed from global to local levels, from research to policy and investment, and across private, public, and civil society sectors. But at the same time, differential approaches are needed to address gender equality and women's concerns in climate-resilient agriculture. This article sets out a conceptual framework for scaling up climate resilient agriculture (CRA) approaches that are gender and socially inclusive by taking into account these constraints and inequalities across wider areas and different aspects of CRA. It builds on gender and climate-resilient agriculture research and project experience to argue that the additional integration of women's empowerment approaches and dimensions into this scaling framework provides the opportunity to promote gender equality while scaling up. It also identifies gaps and areas for further analysis and research. The intention is to identify potential pathways for developing a gender- and socially-inclusive set of options and strategies, in four key dimensions: climate resilient technologies and practices; climate information services that reach under-reached groups; inclusive finance mechanisms; and promoting leadership in decision-making.

Keywords: gender, climate, agriculture, resilience, vulnerability, adaptation, technology, policy

\section{INTRODUCTION}

Limiting global warming to the $2^{\circ} \mathrm{C}$ target that countries have committed to in the 2015 Paris Agreement, and reaching the Sustainable Development Goals by 2030, will require large-scale expansion of climate-resilient approaches in agriculture and food systems. In order to achieve the scale of change required, coordinated action is needed from global to local levels, from research to policy and investment, and across private, public, and civil society sectors.

Men and women farmers experience climate change differently based on their roles in the sector, as well as their rights and opportunities which are defined by variables including gender norms, socio-cultural background, religion, ethnicity, etc. (Fisher and Carr, 2015). These factors 
often explain gender gaps in agricultural production related to the access and control of key resources and inputs (such as land, labor, credit, information, and technology) that also define the differences in vulnerabilities and adaptive capacities of men and women to cope with climate risks. Women also tend to have greater workloads as a result of their domestic and care work that are intensified by climate impacts (Huyer, 2016; ChananaNag and Aggarwal, 2018; Simelton et al., 2021a). Reducing this gap has the potential to improve both agricultural productivity as well as development outcomes including poverty and inequality (FAO, 2016; Resurrección et al., 2019).

Gender differences in priorities and preferences for adaptation also need to be taken into account (Huyer and Partey, 2020). For example, in Kailali district, Nepal, adaptation practices of male and female households varied: more men tended to have access to irrigation and used more pesticides and fertilizer, while women relied more on practices such as weeding (see Table 1). In Bolivia, men tended to focus on large-scale community interventions such as irrigation while women preferred practical improvements such as planting new crop varieties or supplementing traditional revenue with diversified production. Stemming from these types of differences, women and men in different social groups will have different needs and priorities for training, technology, and climate information needs and priorities, based in their differing access to resources, social and gender norms, and gender division of labor (Tall et al., 2014; World Bank, FAO, and IFAD, 2015; Jost et al., 2016) (see Table 2). When they are able to access CSA technologies and climate information, they can be just as inclined to implement CSA practices as men (Twyman et al., 2014; Gumucio et al., 2020). Gender-responsive actions are, therefore, integral to effective adaptation strategies, and approaches are needed to ensure that gender equality and women's concerns in climate-resilient agriculture are addressed.

Climate resilient agriculture (CRA) is about the ability of an agricultural system to maintain viability in the face of climate variability and extremes. This is achieved through improving people's capacity for resilience through increasing the adaptability, and transformability of agricultural practices (Eeswaran et al., 2021). Climate resilient agriculture comprises

TABLE 1 | Adaptation practices of households to deal with the impacts of climate variability on agriculture in Kailali district (\% response of respondents).

\begin{tabular}{lcc}
\hline Practices & Female & Male \\
\hline Repeated plantation and cropping & $(\boldsymbol{n}=\mathbf{5 1 )}$ & ( $\boldsymbol{n}_{\mathbf{4}} \mathbf{4 4 )}$ \\
Shift in cropping days and harvesting & 75.8 & 73.7 \\
Practice crop rotation & 73.7 & 75.8 \\
Increased use of fertilizers & 0.00 & 21.1 \\
Increased use of pesticides & 81.1 & 91.6 \\
Increased use of manure & 75.8 & 89.5 \\
Use of more irrigation & 45.3 & 47.4 \\
Change of seeds & 50.5 & 73.7 \\
Improved crop mgmt. -weeding & 42.1 & 51.6 \\
\hline
\end{tabular}

Source: Bastakoti and Doneys (2020). different approaches such as climate-smart agriculture, that focuses on: sustainable increases to agricultural productivity and incomes, adapting and building resilience to climate change, and reducing greenhouse gas emissions (Lipper et al., 2014). Conservation agriculture is a different CRA approach that emphasizes maintenance of a permanent organic soil cover either from cover crops, inter-crops, and/or from the mulch provided by (i) crop residues; (ii) minimizing soil disturbance; (iii) crop rotation (Kassam et al., 2009).

Gender-responsive approaches to climate-resilient agriculture tend to target pilot or project levels, through participatory and customized gender and social inclusion approaches, developed for specific contexts. But incremental change is no longer considered enough to mitigate and adapt to climate change and enhance food security in time to meet global climate targets. The need to bring about change with more people over larger areas, and through institutions and policies necessitates scaling up of agricultural approaches that are climate resilient (Westermann et al., 2015). At the same time, more attention needs to be given to the structures and inequalities that constrain change and innovation in the poorest and most vulnerable groups. Understanding gender trends in, and local governance of, natural resources, for example, is important to understand how livelihoods can adapt to climate change (Shinn and HallReinhard, 2019). Addressing differences in constraints and opportunities necessitates participatory approaches that embed human rights as well as equality and social justice into both policy

TABLE 2 | Selected women-led agricultural practices and CSA interventions, Nepal.

\begin{tabular}{|c|c|c|}
\hline Key activities & $\begin{array}{l}\text { Key climate smart } \\
\text { interventions }\end{array}$ & $\begin{array}{l}\text { Expected impact on } \\
\text { labor/yield/income }\end{array}$ \\
\hline Weeding & - Weed management & $\begin{array}{l}\text { - Reduction in labor } \\
\text { hours }\end{array}$ \\
\hline $\begin{array}{l}\text { Collection of water for } \\
\text { domestic or irrigation } \\
\text { purposes }\end{array}$ & $\begin{array}{l}\text { - Management of water } \\
\text { harvesting structures } \\
\text { - Management of } \\
\text { irrigation through } \\
\text { solar pumps }\end{array}$ & $\begin{array}{l}\text { - Reduction in water } \\
\text { collection time }\end{array}$ \\
\hline $\begin{array}{l}\text { Horticultural activities } \\
\text { (vegetable cultivation } \\
\text { and high value fruit) }\end{array}$ & $\begin{array}{l}\text { Water-smart } \\
\text { technologies such as } \\
\text { drip irrigation, } \\
\text { especially for } \\
\text { drought-prone areas }\end{array}$ & $\begin{array}{l}\text { Reduction in time and } \\
\text { labor for irrigation, } \\
\text { additional source of } \\
\text { income (leading to } \\
\text { improved food security) }\end{array}$ \\
\hline $\begin{array}{l}\text { Livestock management } \\
\text { (fodder collection and } \\
\text { milking) }\end{array}$ & $\begin{array}{l}\text { - Fodder cultivation and } \\
\text { - Hanagement } \\
\text { - Housing for livestock } \\
\text { dairy } \\
\text { - Livestock } \\
\text { manure management }\end{array}$ & $\begin{array}{l}\text { - Improve milk production } \\
\text { during weather stress } \\
\text { conditions } \\
\text { - Better livestock } \\
\text { management leading to } \\
\text { more secure income } \\
\text { - Increased nutrient } \\
\text { supply for } \\
\text { crop cultivation }\end{array}$ \\
\hline $\begin{array}{l}\text { Weather information, } \\
\text { agro-advisory, and } \\
\text { market information }\end{array}$ & $\begin{array}{l}\text { - Agro-advisory and } \\
\text { market information } \\
\text { customized for } \\
\text { women }\end{array}$ & $\begin{array}{l}\text { - Access to information } \\
\text { for better management } \\
\text { of activities }\end{array}$ \\
\hline
\end{tabular}

Adapted from Khatri-Chhetri et al. (2020). 
and practice (Chandra et al., 2017). For example, in Tanzania, gender and wealth inequalities restricted access to land and water for irrigation and to the financial assets needed for adaptation, so that climate adaptation practices were not scaled up (Chandra et al., 2017; Kristjanson et al., 2017).

This article sets out a conceptual framework for scaling up CRA approaches that are gender and socially inclusive by taking into account these constraints and inequalities across wider areas and different aspects of CRA. It is argued that the additional integration of women's empowerment approaches and dimensions into this scaling framework provides the opportunity to promote gender equality while scaling up, and cites existing research to support this. It also identifies gaps and areas for further analysis to test this assumption.

A great deal of work has been done on participatory approaches to CSA (for example, Bayala et al., 2016; Duong et al., 2016); and work is emerging on gender equality and climate-resilient agriculture (see Rao et al., 2019; Huyer et al., 2021). However, work on gender and socially-inclusive scaling approaches in agriculture or in development is scarce and tends to be analyzed in an operational context of aid or humanitarian approaches, for example Children and AIDs policy brief on "Effective Scaling-up on Social Norms Programming for Gender Equality" (2017), UNICEF's Technical Note on Scaling up Efforts to End Child Marriage (2020), and Women Deliver's "Scaling Up Gender-Sensitive Humanitarian Action" (2018).

\section{What Is Gender and Socially-Inclusive Scaling?}

Scaling is about the use of innovations (new technologies or practices) to impact many people. It involves a sustainable system change in which the impact remains, or gains momentum, without significant additional external inputs (Jacobs et al., 2018). It is a way of expanding results beyond the plot or site level to reach more people over wider areas ("scaling out," or horizontal scaling), as well as to influence institutions and policies ("scaling up" or vertical scaling) (Vernooy and Bouroncle, 2019). Horizontal scaling strategies in climateresilient agriculture include demonstration sites for farmerto-farmer learning [often through self-help groups (SHGs) or producer organizations]; local promotion of options through local government plans, programs, and policies; or privatesector business models. Vertical scaling involves the presentation or packaging of results of practices, technologies, services, processes, and institutional options for influencing large-scale investment plans; mainstreaming of institutional changes; and/or informing policy (Aggarwal et al., 2018). This discussion looks at both vertical and horizontal scaling, or combinations of the two, that might apply given different contextual, geographical, socioeconomic, and environmental factors.

Lipper et al. (2014) proposed a climate-resilient agriculture framework that addresses different scales from small-scale technology implementation at the farm level to multiple integrated interventions at the food system, landscape, value chain, or policy level. The objective was to encourage connected actions by "farmers, researchers, private sector, civil society, and policymakers toward climate-resilient pathways" (Lipper et al., 2014, p. 1068). That framework considers CSA as a combination of synergies and trade-offs between food security, adaptation, and mitigation, that take place from local to global scales. Four "action areas" frame the connections between different levels and dimensions: (1) building evidence of how CSA can contribute to sustainable production; (2) developing capacity of institutions and services to serve farmers; (3) coordinating climate and agricultural policy; and (4) putting in place stable investments (Lipper et al., 2014; see Figure 1). The intention was to identify potential pathways or vectors for scaling of an inclusive set of options and strategies for policy and programming.

This framework did not explore gender and socially-inclusive dimensions of climate policy or action. To assess these options, we propose four dimensions of a gender and socially inclusive approach to scaling CRA, that build on and further develop the CSA framework developed by Lipper et al.:

1. Building "gender and social inclusion evidence": what are the gender and social inclusion gaps and differences in adoption of climate-resilient approaches, and how do women, youth, and other groups benefit from their adoption?

2. Enhancing the capacity of local institutions and services, including women's and community-based organizations $(\mathrm{CBO})$, to close the gender and social inclusion gap through climate services, capacity development, and information, and access to resources and opportunities.

3. Ensuring that gender and women's empowerment are dealt with in coordinated climate and agricultural policy, and promoting the participation and leadership of women, youth, and under-represented groups in policy making at all levels from local to global.

4. Building mechanisms to promote finance and investment with a gender and social inclusion lens (CCAFS, 2016).

Gender equality refers to "equal rights, responsibilities, and opportunities of women and men and girls and boys" and is a precondition to "improve the development process by putting social concerns at the center [Office of the Special Advisor on Gender Issues (OSAGI), 2001]". Empowerment is a multidimensional social process of gaining control over one's life. It involves the power and capacity of people, both individually and as part of their communities and society, to act on priorities and options as well as on issues they define as important (Luttrell et al., 2009). In relation to gender equality, it involves challenging power relations and addressing gender norms in the form of the formal and informal rules and practices that regulate women's lives and constrain their opportunities. It also involves increased control over assets, resources knowledge, and ideology. It focuses on the ability of individual women, through increased agency, to increase their bargaining power in both public and personal lives (Batliwala, 1994; Sen, 1997; Kabeer, 1999). Huyer et al. (2021) identified "four dimensions of gender in/equality and CSA," where participation in decision making at household, community, national, and global levels; access to and control of information, technology, and resources; decreased work burdens and collective action are critical ingredients for voice and agency. Social inclusion consists of improving the ability, opportunity, 


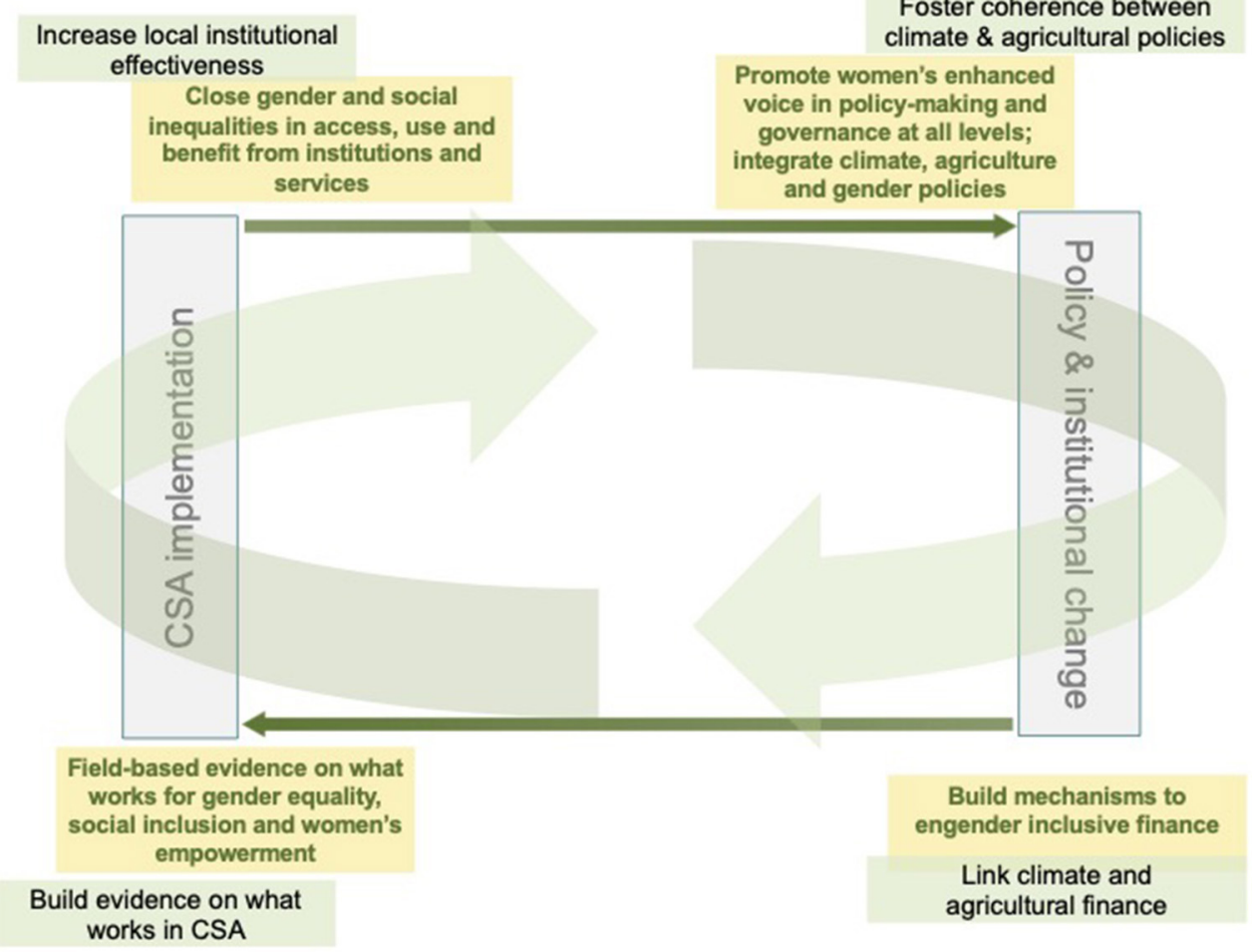

FIGURE 1 | Integrating gender and social inclusion into climate-resilient agriculture.

and dignity of people disadvantaged on the basis of their identity to take part in society. This is achieved through increasing opportunities, voice, and decision making as well as equal access to assets and services and to social, political, and physical spaces (World Bank, 2013).

This paper presents multi-scalar evidence on gender and social inclusion in climate-resilient agriculture and proposes a conceptual framework for policy makers, practitioners, and communities to scale up CRA across wider areas and different sectors, using inclusive approaches. We argue that by adding both inclusivity and women's empowerment, this framework provides the opportunity to scale gender equality and social inclusion, and to identify priority areas for research and action.

\section{GENDER AND SOCIAL INCLUSION IN CLIMATE-RESILIENT AGRICULTURE}

\section{Action Area 1: Evidence for Gender and Social Inclusion in CRA: What Do We Know?}

Agriculture is the largest sector for women's employment in three regions-Oceania, South Asia, and Sub-Saharan Africaemploying over $50 \%$ of women [United Nations Statistics Division (UNSD), 2020]. In LDCs, rural women are significantly more likely than men to be in part-time, seasonal, or low-wage work related to agriculture (UNCTAD, 2020). Typically, women are responsible for subsistence food harvesting, e.g., growing crops, collecting edible forest plants, or gleaning near shore for shellfish (FAO, 2011, 2013). Global youth unemployment rates are high and increasing. Since 1999 the global youth population has increased but the total number of young people engaged in the labor force (either as employed or unemployed) in fact decreased from 568 million to 497 million. This trend reflects growing enrolment in secondary and tertiary education, resulting in a better-skilled workforce, but also that significant numbers of young people are not in employment, education, or training (NEET)-267 million. A large majority of these are young women. An estimated 68 million young people are unemployed globally (NEET) (ILO, 2020).

The gender gap in agriculture exists across a range of assets and resources. Globally, women's land ownership lags behind men's. While $72 \%$ of developing countries have laws in place to support women's ownership of land, it continues to be regulated by customary and local practices in 52\% (United Nations, 2015). For example, men and women inherit land equally in the High Andes of Peru, but do not have equal decision-making control over it (Huyer et al., 2015). Gender and youth gaps also exist in access to financial capital. For example, in 2017, 59\% of women in developing economies had an account at a financial institution, compared to $67 \%$ of men. Forty-six percent of youth, have an account at a formal financial institution, compared with $66 \%$ of adults, with only $18 \%$ reporting savings in a financial institution (Demirguc-Kunt et al., 2018; FAO et al., 2018). In general, women 
are less aware of financing options and opportunities, and their financial literacy is lower (UNCTAD, 2011).

Many studies show that women have greater difficulty accessing resources (land, credit, technology, training, and education) for increasing their output, and little support to move from subsistence farming to higher value, marketoriented production (Huyer, 2016; FAO, 2018). This situation is compounded by lower levels of access to extension and information. While reliable data is not available, the consensus is that in all regions women farmers are excluded from extension systems and information and training to a significant extent (Manfre et al., 2013). Numbers that do exist in isolated cases tend to situate the percentage of women farmers who are reached at $20 \%$ or lower. Women's agricultural production overall is consistently lower as a result (Croppenstedt et al., 2013; Mudege et al., 2017).

Gender differences exist around use, experience, and benefit sharing in relation to culturally defined gender roles in use of natural resources, or ecosystem services. Women manage natural resources in their roles as farmers, seafood harvesters, and household providers, and therefore carry unique and important knowledge about the environment. They also tend to be the main collectors of water and fuelwood, often in unsafe conditions (FAO, 2011, 2014). Research across eight communities in Kenya and Mozambique found that different dimensions of well-being are affected by different aspects of ecosystem services, and are valued differently by men and women. This is an outcome of gendered knowledge systems, gendered behavioral expectations, gendered access to resources, and gendered institutions (Fortnam et al., 2019). Added to this, differing tasks and roles by gender lead to differences in share of income from ecosystem services. Women tend to be restricted to low-income activities and there tends to be gender variance in the valorization of different ecosystem services; for example, women may ascribe value on a non-monetary basis, such as contribution to social relationships and household food security (Yang et al., 2018). Analysis of adaptation responses within farming households show that women and men exercise decision making power over different on-farm and off-farm activities. Some research finds that when wives are more involved in intrahousehold decision-making on adaptation options, they are more likely to choose to be engaged in non-farm income-earning activities, and their households are more likely to plant cover crops and drought-resistant crops (van Aelst and Holvoet, 2018), while there is evidence that women's participation in natural resources user groups at the local level contributes to more sustainable environmental management (Agarwal, 2010). Formal institutions (such as resource permits or resource user groups), can create obstacles for women's participation in livelihood activities and decision-making, while informal institutions can define women's and men's opportunities for use and benefits. The under-acknowledgment of women's roles in natural resource management has led to an undervaluation of their unpaid and household work, as well as the economic and societal benefits they provide to the environmental sector (Aguilar et al., 2015).

Young farmers experience similar constraints. Young people, especially young (unmarried) women, do not have access to or rights over assets, particularly productive land (Amsler et al., 2017). Increased rates of land fragmentation, due to inheritance, reduces the viability of the family farm as a livelihood strategy, potentially pushing some family members out of agriculture. On the other hand, the limited potential to inherit or gain access to land (e.g., Madagascar, Malawi, South Africa, Zambia, and Zimbabwe) may also cause young people to leave agriculture (Bullock et al., 2020). Research with young farmers in East Africa found that access to resources-financial resources and credit in particular-was considered the primary constraint to establishing their own agricultural production (Amsler et al., 2017).

As a result of these varying gender gaps, women and men farmers in developing countries, as well as young farmers, have different vulnerabilities and capacities to deal with the impact of climate change on agriculture, and to adopt CSA practices (Agwu and Okhimamwe, 2009). Rural women in particular are at high risk of negative impacts from climate change, due to household responsibilities as well as increased agricultural work from male out-migration. One of the important effects of environmental stress in farming systems (such as those imposed by climate change) is the intensification of women's workloads, while another is decreases in assets of poor households (Agwu and Okhimamwe, 2009; Kristjanson et al., 2017).

Climate variability and weather-related shocks affect women's and men's assets in different ways:

- Cultural norms can affect changes in control and ownership of assets during drought, e.g., in one case women gained increased control of the household's livestock because men sold their livestock first (Kristjanson et al., 2014).

- Women and men are also changing cropping practices in response to climate variability, with different impacts on control of the income from crops and on workloads (Kristjanson et al., 2017). Women are using local or traditional knowledge to fill gaps in resources or to respond to impacts (Mcleod et al., 2018; van Aelst and Holvoet, 2018).

- Gender roles can change in some situations, e.g., in response to economic imperatives or household livelihood requirements (Gonda, 2016).

- Non-farm job migration is a risk management strategy among smallholder farmers, where the destination is associated with relative poverty, and in turn results in gendered impacts of natural disasters, and ability to recover (Simelton et al., 2021a).

Lower rates of access to key resources affects women's ability to adopt climate-smart or climate-resilient practices (Kristjanson et al., 2017). For example, in Ethiopia the adoption of such practices by women smallholder farmers uptake was affected by limited access to credit, and extension, lack of membership in cooperatives and water user associations, lack of access or use rights to land, lack of skills training and information, and restricted mobility (Tsige et al., 2020). In Malawi women farmers often opted to partial adoption of CSA practices, intermixing them with more labor-intensive practices for reasons of cost (Ashby et al., 2012; Mutenje et al., 2019).

Women and men also face differing challenges and opportunities to access climate-related information, use it to improve farm management, and benefit from those improved 
TABLE 3 | Constraints to effective use of climate information delivered through mobiles phones in the CCAFS CSV sites in the Lawra-Jirapa district of the Upper West Region of Ghana.

\begin{tabular}{|c|c|}
\hline Male & Female \\
\hline $\begin{array}{l}\text { Limited training on interpreting } \\
\text { weather information received }\end{array}$ & $\begin{array}{l}\text { Little or no formal education hindering } \\
\text { our ability to read and understand the } \\
\text { text messages sent by the Esoko } \\
\text { platform }\end{array}$ \\
\hline $\begin{array}{l}\text { The forecast information is } \\
\text { sometimes different from the actual } \\
\text { weather condition }\end{array}$ & $\begin{array}{l}\text { Periodically, educated community } \\
\text { members unable to correctly interpret } \\
\text { text messages }\end{array}$ \\
\hline Bad network connection & Expensive call charges \\
\hline $\begin{array}{l}\text { Long waiting times on calls placed } \\
\text { to the call center }\end{array}$ & $\begin{array}{l}\text { Lack of access to mobile phones as the } \\
\text { service is phone based }\end{array}$ \\
\hline $\begin{array}{l}\text { Periodically, the translators at the } \\
\text { Esoko call center are not available } \\
\text { and they do not call back either }\end{array}$ & $\begin{array}{l}\text { Lack of means of transportation on } \\
\text { reported market days in various } \\
\text { communities prevents farmers from } \\
\text { moving to sell farm produce }\end{array}$ \\
\hline
\end{tabular}

Source: Partey et al. (2020).

management decisions (Tall et al., 2014; Carr et al., 2016). Factors related to socio-cultural norms, the gender division of labor, resource control, and decision-making power can affect women's and men's differing capacities to use weather and climate information to manage risks and make changes in livelihood planning (Roncoli et al., 2011; Venkatasubramanian et al., 2014). In one example, biased institutions and gender differences in group participation and networks were found to inhibit women in Senegal from accessing communication channels where weather and climate information is shared (Diouf et al., 2020).

Women and men may have different preferences for content and format of climate service products, which may relate to specific tasks and time available to absorb the information, as well as gender roles and norms relating to women and men's responsibilities (Duong et al., 2016, 2017; Partey et al., 2020) (see Table 3). In Vietnam, women preferred agro-advisories that contained both graphic and written information, so that their children could read them while they attended to household chores. Men preferred the option with more numbers (Duong et al., 2017).

\section{Action Area 2: Enhancing the Capacity of Local Institutions and Services, Including Women's and Community-Based Organizations, to Close the Gender and Social Inclusion Gap}

The impact and scale of climate change requires social and institutional over and above individual level action. Enhancing local institutions is a way to increase agency for those with the strongest local knowledge who may be marginalized from formal institutions and processes. Institutions relevant to climateresilient agriculture include: collective action for land and water management, multi-stakeholder processes for local and national planning, comprehensive risk-management, and crisis-response mechanisms, social protection programs, and access to inputs and markets to underpin farmer ability to adopt new practices
(Lipper et al., 2014). Supporting institutions include national extension programs, rural credit lenders, NGO- and private sector-support systems as well as local CBOs. Such institutional approaches often go beyond provision of climate-specific support (e.g., access to drought-resistant crop varieties) to a much broader base of generic capacities, such as social protection, particularly in the context of working with women. Empirical evidence from Brazil, Mexico, and USA suggests we need both; investing in either specific or generic support alone does not lead to climate resilience (Vermeulen, 2015).

There are differences in how women and men can access and benefit from climate support institutions and services. In general, the trend is that women will interact with informal, local-level, and family or social based networks, while men tend to connect with formalized institutions such as government, extension, international NGOs, etc. Extension agents, farmers' organizations, agri-service providers, and other sources of climate and agriculture information tend not to reach women very well (Manfre et al., 2013). Analysis of data from 15 sites in West Africa, East Africa, and South Asia, found that women interacted more with local organizations than men across the entire range of sites. In India, men did not interact with local organizations at all. In all regions, women tended to value community-based organizations (CBOs) most highly, while men preferred international NGOs, government organizations, and CBOs almost equally. There were also gender differences in area or topic of interest, with women much more interested in food security, while men were more interested in agricultural productivity information. Women were also interested in a wider range of information, including health issues, reflecting their role in the household (Cramer et al., 2016). Perez et al. (2015) found in Africa an even more marked difference in access, finding "tremendous anti-women biases" in formally registered, public and private agriculture and livestock organizations, which as a result provided support primarily to men. As a result, women tended to engage in mutual insurance and risk-sharing networks, and access non-agricultural services from external social support institutions.

While media or technology-based information channels can reach women with climate information, there tend to be marked gender differences in reach, in favor of men (Tall et al., 2014; Gumucio et al., 2020). For example, in Kenya, a greater proportion of women perceive barriers to mobile agriculture/livestock services and are less aware and knowledgeable about how to use m-services in general (Krell et al., 2020). The top three reasons given for why women did not use mobile agriculture or livestock services were: Not aware; Not available; Don't know how. Other reasons included "[Information gotten from] Other sources," "No ID," "Language barrier," and "Not relevant" (Krell et al., 2020).

A variety of factors govern these gendered barriers in use. A report by GSMA Connected Women (2015) concluded that cost is the greatest barrier to ownership and usage of mobile phones for women, due to their reduced financial independence compared to men. Although mobile phone use is widespread globally for both men and women, a gender gap in mobile use is widening in LDCs (UNCTAD, 2020). The increased 
costs associated with smartphone ownership and use present a potential barrier to women's ownership of smartphones in almost all regions, which may explain why women are behind men in smartphone ownership (20\% fewer globally). Research in Africa has found (Wyche and Olson, 2018) found that mobile use and access among rural women remains limited due to a range of reasons including technical literacy, mobile phone, and access costs, perceptions of the Internet, time required to learn how to use the Internet, and seasonal income fluctuations. Other factors in m-services (and therefore climate services) use include participation in farmer organizations, level of education, and smartphone ownership. Each of these factors interacts with gender: age and income are not significantly related to farmer use of mobile phone services; smartphone ownership is a metric of individual wealth and assets that is significantly related to m-service use (Krell et al., 2020).

Using a range of different media and communication channel approaches has been shown to be effective to reach women (Tall et al., 2014). However, once access barriers are addressed, issues of content can remain: information may be targeted to or produced by men and therefore often less useful for women's production activities (Carr et al., 2016). Women are also interested in information outside of their own production activities. This may include information on their husband's agricultural production, allowing them to participate more significantly in household farming decisions (Mittal, 2016); on health and nutrition, or on agricultural and non-agricultural livelihoods (Martin and Abbott, 2011; GSMA, 2012).

A project in the Vietnam village of My Loi integrated a genderresponsive approach in climate-smart agriculture practices that had empowerment results. CSA activities were combined with gender equality events and implicit activities to gradually nudge the project toward gender integration. Facilitators and project staff were trained in inclusive and participatory approaches from the start. For example, group membership in farmer groups for managing savings and loans or preparing agro-advisories based on seasonal forecasts was intentionally kept open for husband and wife to participate interchangeably. According to farmers, the need to be prepared and informed at the next meeting led to more information sharing at home. Empowerment results of information sharing at home included joint decision making between women and men; and women said that by preparing the advisories themselves they understood the information presented and were therefore more confident in making public presentations and comments (Simelton et al., 2018).

\section{Action Area 3: Inclusive Climate Policy and Leadership}

Globally, gender imbalances exist in favor of men in policy and decision making. The representation of women in elected seats is increasing, but according to the International Parliamentary Union, women make up only 1/4 of members of Houses of Parliament and Senate globally (IPU, 2021). Representation in decision making at local levels is greater-41\% in Central and Southern Asia, 35\% in Europe and North America, 32\% in Oceania, and $30 \%$ in sub-Saharan Africa, for example
(UN Women, 2020). At both local and national levels, women are less likely to occupy executive branch posts or key cabinet positions. Women do play leadership roles in social movements and civil society organizations, but mostly in gender focused organizations (Domingo et al., 2015). Scaling of gender and social inclusion will require both greater participation of women in decision making at global, national, and local levels; as well as mainstreaming of gender and social inclusion into agriculture and climate policy.

Compared to other international environmental or science platforms, the integration of gender equality into climate policy has been slow at both global and national levels (Ampaire et al., 2020; Huyer et al., 2020). A review of NDCs submitted to UNFCCC by the end of 2019 found that many NDCs identify gender as a cross-cutting policy priority or commit to mainstreaming gender into climate actions, strategies and policies, but don't articulate specific strategies or actions. While gender-sensitive climate policy instruments in some countries inform NDC priorities and actions; few countries include gender outcomes in monitoring or MRV. As in other areas of climaterelated policy, the vast majority of current NDCs do not address structural causes of gender inequalities, and gender references are most often embedded within vulnerability discourses. Less than half make references to gender mainstreaming or national human rights frameworks. Ten countries have developed gender and climate change plans in the last few years: Bangladesh, Cambodia, Haiti, Kenya, Mozambique, Nigeria, Panama, Peru, Tanzania, and Zambia (Huyer et al., 2020).

This lack of recognition of gender in relation to agriculture and climate change is seen also at the national level. Research on agriculture and natural resource management policies in Uganda found that gender and climate issues are generally treated as cross-cutting issues, not as a priority or with a budget allocation. Gender mainstreaming in most of the reviewed policies is an addendum to rather than an integral aspect of policy. Related research in Tanzania found that gender is poorly integrated across departments, and budgeting is implemented inconsistently across government levels. In both countries, degree of gender mainstreaming in policies decreased along the spectrum from global to national to district levels. In their review of agriculture policies in several countries in Latin America, Gumucio and Rueda (2015) found that while gender can be quite wellintegrated into agricultural policies in a region, this does not necessarily translate to climate change policy. They note that seven countries in Latin America conducted gender-sensitive consultations that resulted in gender integration in climate planning. Simelton et al. (2021a) argue that agricultural policies in combination with the Confucian culture in Vietnam have detracted from women's mobility and visibility outside the domestic sphere.

Analysis of stakeholder engagement around gender and social inclusion in policy processes shows that analysis of existing policies and programs is a critical entry point for identifying points of leverage, the type of stakeholders to engage, and how to engage them in the processes that focus on integrating gender in climate policy. Working with influential stakeholders who have the capacity and interest to address gender considerations yields 
more positive results. Mechanisms to address power relations need to be in place for gender considerations to be voiced and integrated and include women in decision-making processes. Colearning and co-development of knowledge products cultivate interest and commitment among stakeholders to address gender issues (Mulema et al., 2021).

At the household and local level, lack of control over natural and other resources is related to and often a result of limited access to positions of leadership and decision making. Women's participation in household and farm-level decision making varies according to region, marital status, and socio-economic level (see Acosta et al., 2020). Research indicates that participatory decision making in a household is positively related to investments in the common farm. Participatory decision making is also associated with more cooperative outcomes such as sustainable intensification, integration of women's interests, greater equity in domestic tasks, more equity in control over cash crop income, and improved livelihoods (Acosta et al., 2020).

\section{Action Area 4: Gender and Socially-Inclusive Climate Finance}

Women's access to agricultural finance remains lower than men's in general (FAO, 2017), for reasons of ownership of collateral such as land and level of education (Alao et al., 2020), ownership of bank accounts (Demirguc-Kunt et al., 2018) socio-cultural reasons, trust, and lack of documentation (Sioson and Kim, 2019). While both poor women and men tend to have less access to formal financial services, a gender gap appears in richer households: women will continue to use informal financial services while men in the same household will tend to start sourcing more savings and credit services from formal providers, particularly from banks. Additionally, women can have less opportunity to diversify their agricultural activities, for example, into livestock, and as household incomes increases, women continue to be dependent on agricultural activities while men are more likely to diversity into non-farm economic activities (Hernandez et al., 2018).

Attention in climate finance to date has been focused on macro issues, i.e., the level of finance required to address climate change globally, and whether sufficient or new funds are available to developing countries. Social issues such as climate justice or enabling climate finance at the community level tend to be overlooked (Wong, 2016). Gender equality approaches in climate finance have tended to focus on analysis of gender policies in major finance institutions such as the Global Environment Facility (GEF) and Green Climate Fund (GCF), with little attention to gender issues in climate finance at the local level (see Schatalek and Nakhooda, 2014). Where climate finance mechanisms (CFM) take into account poverty alleviation they will not necessarily address gender equality, as in Indonesia for example, where systems for monitoring and evaluating gender as well as poverty outcomes are weak or non-existent (Atmadja et al., 2020).

Recent research on climate finance in agriculture reveals that access to credit is one of the major barriers to women's adaptation to climate change in agriculture, and one important source of resilience (Owombo et al., 2014). Initiatives and approaches are emerging to address this imbalance such as gender-responsive climate risk insurance (CRI). Climate risk insurance can increase women's access to credit in that small unit costs make it more affordable and access via mobile phone eliminates the need to travel long distances to buy it. Gender differences in use, literacy, and preferences for CRI are being tested. In Senegal and Burkina Faso, women farmers were less likely to purchase agricultural insurance and more likely to invest in savings for emergencies, making rainfall insurance less used by women. Other studies have suggested that differences in risk aversion, distrust in insurance institutions, lower levels of financial literacy, and relevance to women's activities or crops may mean that women will be less likely to purchase insurance (Delavallade et al., 2015; Akter et al., 2016). Other factors constraining or affecting women's uptake of insurance include use of mobile phones or text-based platforms which tend to be more accessible to men, education level, and household decision making patterns (see section Action Area 1: Evidence for Gender and Social Inclusion in CRA: What Do We Know?).

Insurance programmes that target gender or social equity can result in high levels of adoption among women. The World Food Programme and Oxfam America "R4 Rural Resilience Initiative" explicitly targeted women's groups to participate or linked insurance with work opportunities, to ensure it was accessible to vulnerable households. In Kenya, meetings were held with $1,153 \mathrm{R} 4$ participants ( $84 \%$ women) across 16 sites to inform them about the payout mechanism. RT also encourages gender equity in leadership in community planning and management committees: $45 \%$ of leaders in the initiative are women, leading to better identification of insurance needs across different populations [Greatrex et al., 2015; World Food Programme (WFP) Oxfam America, 2018].

Another model for women's financial inclusion builds on village savings and loans associations (VSLAs) for access to loans and exchange of knowledge. In Vietnam, membership of VSLAs promoted access to finance and training on coffee production, and was linked to increased equality in household decisionmaking as well as increased sharing of domestic responsibilities. Decision-making over large purchases and use of income were the areas with the biggest improvement, especially for VSLAmembers who researched market information before engaging with potential coffee buyers and informing their negotiations with buyers. Active gender and finance training translated to real changes in gender dynamics in this case, while membership in a VSLA improved women's financial literacy and negotiating abilities. Husbands of women VSLA members reconsidered household gender roles and shifts were documented toward equal sharing of responsibility and decision-making. Anecdotal evidence suggests that male household heads also appreciated that their wives could get rapid access to loans (Simelton et al., 2021 b see also Bannor et al., 2020). Impacts of VSLAs are not globally universal and need to be understood in each context. In Ghana, a study on 1,200 women showed that women's VSLA participation had significant impact on off-farm income but not on poverty (Bannor et al., 2020). In contrast in Malawi, VSLAs 
contributed both to savings and household nutritional intake (Ksoll et al., 2016).

A popular approach to financial inclusion for women is SHGs. In India, the India National Rural Livelihoods Project has organized 75.7 million rural women into 300,000 (SHGs) at the village, sub-district, and district levels since 2011. Self-help groups promote saving among the rural poor in order to qualify for credit and financial services from formal banks, microfinance institutions, insurance companies, and other financial institutions. Member households have accumulated more than $\$ 70$ million in total. Decision making increased for SHG members, who experienced increased confidence in dealing with government officials and community leaders ${ }^{1}$

\section{GETTING TO EQUALITY AND EMPOWERMENT IN CLIMATE-RESILIENT AGRICULTURE}

Evidence is emerging that climate-resilient agriculture can be scaled up in a way that benefits women, youth, and other social groups-while reaching the hundreds of millions of farmers required to achieve resilience and change at a large scale (Vernooy and Bouroncle, 2019). But at the same time, gender and social inclusion approaches are needed to grapple with inequalities, local environmental and economic conditions, social context, and norms, if scaling approaches are to be empowering as well as inclusive. Gender equality and empowerment frameworks have been developed in other contexts-agriculture (Huyer et al., 2021), natural resources management (Mello and Schmink, 2017) and others.

Key elements of equality and empowerment in CRA are outlined here (as shown in Figure 2):

Agency, or the ability to make decisions in one's life, exercise leadership, and engage in collective action. Women and youth can develop new capacities that are recognized by others, and that can open up livelihood options and increase their status in households and communities (see Kabeer, 1999; Kantor et al., 2015).

Institutional structures and social/gender norms can define and influence agency, as well as women's, girls', and youth control over resources (van Eerdewijk et al., 2017).

Resources, that consist of: land, time, social capital, credit, agricultural inputs and services, and information; as well as education, critical thinking, and skills. Accessing and making decisions about resources may require contestation of power relations and social norms (Kabeer, 1999; Huyer, 2016).

In the context of climate-resilient technologies and practices that increase adaptive capacity of both women and men, three crucial ingredients need to be incorporated. The role of technology use and access should be focused on in its own right. Technology is an important aspect of climate-resilient agriculture in terms of reducing climate impacts on agricultural systems, increasing

${ }^{1}$ https://www.worldbank.org/en/topic/agriculture/brief/women-farmers-gettingto-equal resilience to climate change, and reducing emissions. Climateresilient technologies and practices address may include changes in crop management and production techniques, low-impact technologies for irrigation or harvesting, or increases in inputuse efficiency, for example Aggarwal et al. (2018). Genderresponsive technology reduces women's work burdens (KhatriChhetri et al., 2020), increases their agricultural production, and supports improved livelihoods (Carr and Hartl, 2010). In general, however, women access, use, and adopt technology less than men, for reasons of cost, targeting of men's activities and priorities, and knowledge restraints (UNCTAD, 2021a,b).

The second ingredient, access to and use of digital technologies for information, early warning, and other uses, is a critical aspect of climate resilience for women (Porciello et al., 2021a; see section Climate Services: Information for Empowerment below).

The third crucial ingredient of gender-and socially-inclusive scaling for climate-resilient agriculture is collective action and organizing through women's and producer organizations. Farmers' organizations for example, can act as a conduit for farmers' views to be brought to the attention of policy makers, and can influence policy. The Asian Farmers' Association is working with three member organizations in Cambodia, Philippines, and Indonesia, to strengthen the capacities of grassroots farmers' organizations to engage in national, regional, and international dialogues on large scale land acquisitions (LSLAs). This involved learning how to articulate and claim their land rights, negotiation skills, and how to engage with governments and land investors. In multi-stakeholder consultations they analyzed national laws and brainstormed on options for the inclusion of peoples' organizations in LSLA decision-making processes (International Land Coalition ${ }^{2}$ Promoting women's leadership in farming organizations will increase representation of their views and perspectives (IFAD, 2015).

Women's, youth, farmers', and CBOs can act as platforms for establishing new technologies and practices in spreading information and new practices to members, as well as providing a base for joint purchase and management of technologies and practices. In East Africa, a common local strategy is the establishment of CBOs (Recha et al., 2017). Experience in Kenya and Tanzania has found that these local community organizations can also be platforms for agricultural learning, delivery of farmer advisory services and agricultural inputs, mobilization of financial resources for loans, and mobilization of farm labor, for example in the construction of soil and water conservation structures. They also served as platforms for demonstration farms and agricultural knowledge. Comprised of mixed, women-only, and youth groups (with $50-80 \%$ women members), the $\mathrm{CBO}$ platforms acted as an adoption platform for technologies, and innovations such as resilient varieties of root crops (cassava and sweet potato), cereals (maize, millet,

${ }^{2}$ International Land Coalition. Inclusive Decision Making. Inspired Learning from ILC Database of Good Practices, ILC. Available online at: https://learn. landcoalition.org/en/good-practices/learn-share-and-be-inspired-learningdatabase-good-practices-inclusive-decision-making/). 


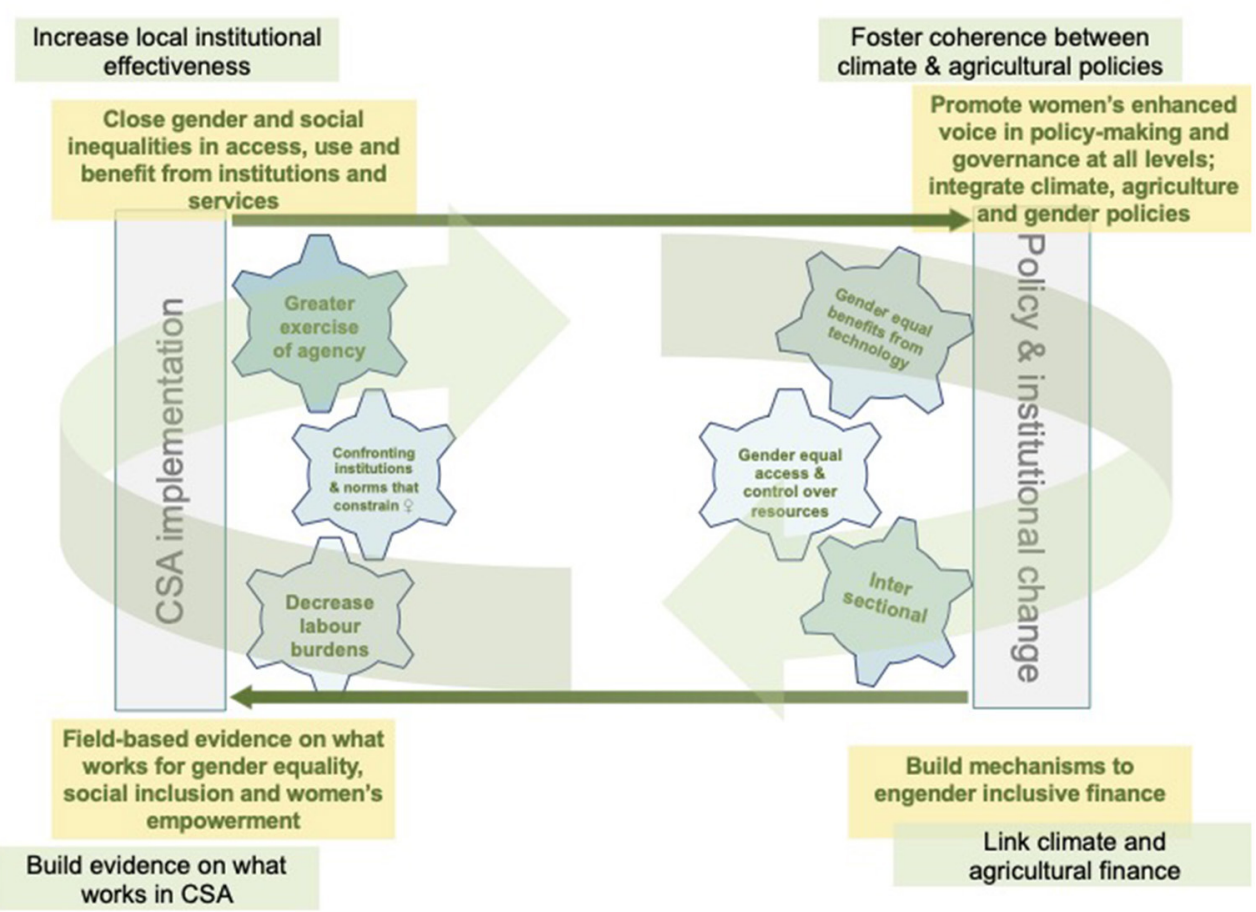

FIGURE 2 | Gender equality and empowerment in climate-resilient agriculture.

sorghum), and soil and water conservation strategies (Recha et al., 2015; Radeny et al., 2018).

Community organizations also promote access to mobile services and information-in rural Kenya, membership in a farmers' organization was found to be one of the factors affecting greater usage of m-services (Krell et al., 2020), while inclusion of women's groups and networks can help women overcome barriers to communication channels (Rengalakshmi et al., 2018; Huyer, 2019).

\section{TOWARD A FRAMEWORK FOR GENDER- AND SOCIALLY-INCLUSIVE SCALING OF CLIMATE-RESILIENT AGRICULTURE}

How do these aspects of gender equality and empowerment combine with climate-resilient agriculture approaches to produce gender-inclusive scaling? As Aggarwal et al. (2018) note, scaling occurs both horizontally and vertically. Key aspects include government plans, programs, and policies; or privatesector business models and investment plans; mainstreaming of institutional changes; and/or informing policy. Vertical scaling translates from household to local to national to global levels, through one or more of these mechanisms, while horizontal scaling may translate across regions, communities, or countries.

The potential for an approach to gender and socially-inclusive scaling in CRA that is also empowering is seen through the emergence of promising models that incorporate the four dimensions of gender equality with the key elements of vertical and horizontal scaling-as shown in Figure 3.

\section{Scaling the Evidence Base on Gender Equality in Climate-Resilient Agriculture}

Building women's knowledge of climate-resilient practices increases their empowerment: women in Vietnam who participated in training sessions on pest management and livestock rearing experienced significant levels of increased confidence, increased status in the household, and increased contributions to household income (Chi et al., 2015). This result is supported by research in Ethiopia, where the law explicitly encourages women to participate in public community and training sessions, that in itself can bring about changes in gender roles. The visible presence of women in public meetings, training sessions, and in farm-field activities catalyzed changes in community norms about women's capacities (Manlosa et al., 2019).

Women often do not have the resources to implement adaptation solutions in farming, even if they are equally aware of its impacts (Kristjanson et al., 2017; Assan et al., 2018). Initial research, however, indicates that women can experience empowerment benefits from the adoption of climate-resilient practices and technologies, including increased decision making over household and farming expenditures, increased access to employment and incomes, and greater participation in village decision making (Hariharan et al., 2020). 


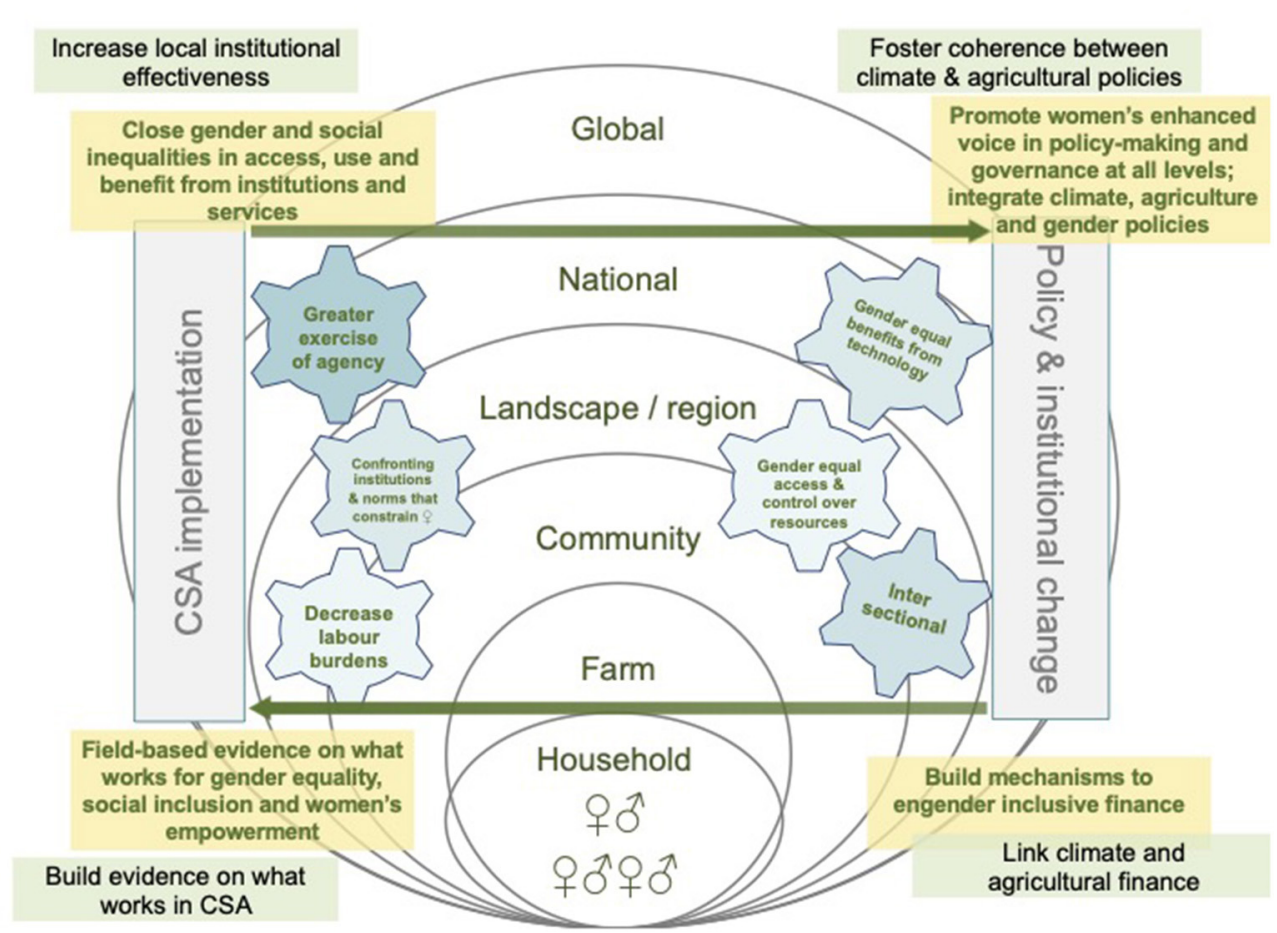

FIGURE 3 | Empowerment and CSA: a GSI scaling framework.

\section{Climate Services: Information for Empowerment}

As a platform for scaling, climate services can contribute to gender equality if they address the needs and priorities of both women and men in rural areas, increase their resilience to cope with climate change, increase their incomes and production, and provide a means for women to challenge gender norms through public discussions and airing of their views (Sterling and Huyer, 2010; Sekabira and Qaim, 2017; Huyer, 2019). In India, access to weather forecasts, agro-advisories, along with capacity building to act on advisories supported women to make informed agricultural decisions in India, increased their role in decision making on the farm (Mittal, 2016; Rengalakshmi et al., 2018), and encouraged them to implement new adaptation practices (Chanana et al., 2018).

The PICSA methodology is a participatory approach for extension workers and farmers to analyze seasonal and shortterm forecasts in the context of historical climate data to inform farm-level decision-making. Through the Rwanda Climate Services for Agriculture (RCSA) project the PICSA approach has now reached all of Rwanda's districts. The RCSA project is characterized by strong leadership of rural women, as farmer promoters, agronomists, socio-economic development officers, as well as farmers. In one example, CGIAR, the World Vegetable Center and the Institute of Rural Economy (IER) trained farmers on soil fertility management, water conservation, and crop production, educating female farmers on varieties and technologies that were unknown to them. For example, women had grown garden products only during the cold season, unaware that they could be produced during the rainy season as well. "During the rainy seasons, the water washes away the soil and our seedlings," said Mayama Yatoura, president of the women's group involved in market gardening. "This demotivated us a lot. In the climate-smart village (CSV) we learned about the new technique of raised gardening boards and our activities now continue all year long, allowing us to generate more income and improve our nutrition (Dembele and Samuel, 2019)."

In My Loi CSV, Vietnam, women and men have autonomously started to share information and exchange knowledge via social media platforms as climate-resilient approaches are being scaled out to include more farmer groups. As of September 2021, 5 years after the project started, the social media groups consist of over 300 members in the district, and it is estimated that $10 \%$ of the provincial Farmers' Union website's 10,000 daily viewers visit for agroadvisories (see https://www.facebook. com/vietnamfarmersunion and http://vietnamfarmerunion. vn/SitePages/TrangChu.aspx). Posting context-specific agroadvisories online has been a promising strategy for spatial scaling of climate-smart agriculture-as resilient practices are recommended and presented automatically as part of the advisory-and for integrating gendered perspectives, since the content is decided by the members themselves. This semi-digital, but self-managed knowledge exchange and generation empowers both women and men farmers to exchange and use their own knowledge, and not be totally reliant on external information. The value-chain from producer to user of climate services 
is well-coordinated, and farmers can give direct feedback to meteorologists and extension for use of terminology that farmers understand and indicators that farmers need. Institutionally, scaling is possible through local policy support and donor support, building on evidence generated in the first stage. Practically, this bottom-up model has agroecological limitations for scaling, but promoted social learning and empowerment and new approaches for local organizations to work with farmers where top-down siloed models had previously failed.

Digitally-based climate information and services are inaccessible to women, unless the gender digital gap is taken into account. Despite gains in recent years, a gender digital gap in mobile ownership and access to the Internet persists (20\% in 2020 compared to $27 \%$ in 2017), as well as ICT skills. South Asia has the widest mobile internet gap, at $51 \%$ (down from $67 \%$ in 2017). A gender gap of $8 \%$ in ownership of mobiles exists across low- and middle-income countries, ranging from 23\% in South Asia to $13 \%$ in sub-Saharan Africa and $9 \%$ in North Africa and the Middle East (GSMA, 2020). In all regions the gap is greater in rural areas than urban. Reasons for the gap include access, affordability, lower education levels and lack of technological literacy, and gender norms (Borgonovi et al., 2018). Unequal access to digital agriculture applications risk spiraling other gender gaps: more men than women are connected via digital agriculture applications, leading to greater use by men of these apps who also therefore share data with big-tech companies. This leads to the risk that advisory information systems for farmers will reiterate and entrench male perspectives and needs, so that women's needs are excluded in from the innovation and development of new services in the sector (Porciello et al., 2021b).

\section{Integrating Equality and Empowerment Into Climate Policy, Decision Making, and Leadership}

With gender being significantly included in the United Nations Framework Convention on Climate Change (UNFCCC) only comparatively recently in 2017 in the Gender Action Plan (Farnworth et al., 2017, p. 7), the process of integrating gender into climate policies has been long. Working with stakeholders and policy makers is one strategy for policy change, another is through women and socially-inclusive advocacy and organizing. The literature on advocacy for gender inclusion in policy making as well as the experience of women's groups provides lessons on integrating gender concerns into environmental policymaking (Chen, 1995; Ampaire et al., 2020). Through coordinated advocacy women's NGOs played a big role in shaping the policy debates in the leadup to and during three major UN conferences: the Rio conference on environment (1992), the Vienna conference on human rights (1993), and the Cairo conference on population (1994), Chen's analysis of the international women's movement efforts to make themselves heard in United Nations conferences points out the success of coordinated action by women's groups added to participation in preparatory policy processes, pointing out the need for continued advocacy in these forums to ensure policy change
(Chen, 1995). Activism by women's and social groups remains a major strategy to influence global climate policy, through groups such as Women's Environment and Development Organization (WEDO) and the Women's and Gender Constituency of the UNFCCC.

At the national level, women's and other civil society representative groups are increasingly becoming more in consultative development processes in different aspects of climate policy, including, in the case of Ghana, in its CSA Policy Platform (UNDP, 2016; Zougmoré et al., 2019; WEDO, 2020). In its roadmap to integrating gender equality in NDCs, UNDP notes the important of engaging in consultations with women's stakeholder organizations for representation of key concerns, perspectives, and in turn empowerment of women in national policy processes (2016). Krizsan and Lombardo consider the degree of participation of women's and civil society's organization and the authority bestowed to these groups as a process criterion of empowerment (Krizsan and Lombardo, 2013, p. 85). Similar to Chen, in their analysis of gender inclusion in climate policies in Latin America, Gumucio and Rueda suggest that women's groups be brought into the process at an early stage to ensure substantive integration of gender issues in climate policies as well as capacity development for effective participation (Gumucio and Rueda, 2015, p. 46). The literature also stresses the need to ensure that gender equality's multidimensionality is stressed from the beginning as well as to pay attention to the composition of the "room" or people sitting at the table, in terms of gender balance and expertise (IUCN, 2011; Gumucio and Rueda, 2015, p. 46). Similarly, stakeholders should be provided effective support through workshops, training or provision of technical resources (Chingarande et al., 2020). Finally, Mansuri and Rao, in their 2012 analysis on participation in development programmes, also commented on the need to analyse the influence of facilitators on community participants' responses in participatory processes (Mansuri and Rao, 2012).

Work with a range of national government stakeholders and machineries, such as Ministries of Women, and gender focal points or champions within sectoral ministries, can also be an effective avenue for integrating gender into climate policy (UNDP, 2016; Mulema et al., 2021). The process to develop the Nigeria National Action Plan on Gender and Climate Change was primarily driven by the Ministry of Environment Department of Climate Change and the Women Environment Program, with reviews and inputs from different Ministries, CSOs, media, and academia (Federal Republic of Nigeria, 2020).

\section{Inclusive Finance Strategies for Scaling Resilience}

Innovative financing includes working through local women's groups by providing credit access and production support. The IFAD approach of working with District Value Chain Committees (DVCCs) builds on local women's groups to access finance and production support. In Northern Ghana, DVCCs manage planning, implementation, coordination, and monitoring of activities in maize, soya, and sorghum value chains. District Value Chain Committees include buyers, input 
providers (seeds and fertilizers), service providers (extension and tractor services), financial institutions like rural banks, and farmer-based organizations (FBOs). Empowerment results for women farmers included: ability to buy additional pieces of land, attending management training, decision making power over their own income, engaging in non-traditional activities such as buying and operator a truck, employing other people in small and medium sized enterprises.

\begin{abstract}
"I can send all nine children to school and guarantee at least three meals a day for all, including my husband when he is home. I also employ 15 women who work for me as sub-market operators. As a result, they have stayed in the village and do not need to migrate to Accra to look for jobs. I am also planning to buy a new and big house. I am also thinking to buy a truck so I can transport easily the produce I buy from the remote communities. I hope to receive the support from NRGP through the matching grant when I save enough."

Ayishetu Mbilla Mohammed, a 55-year old farmer and trader $^{3}$
\end{abstract}

Mobile money has significant empowerment effects for women and those without formal bank accounts, although a gender digital gap persists in ownership of mobiles and internet access. In Kenya, over a period of approximately 5 years, mobile money enabled 194,000 households in Kenya to move out of povertythe majority female-headed. M-PESA influenced changes in financial behavior in the form of financial resilience and saving, with many moving out of agriculture and into small business as a result. Mobile money has also been shown to be a platform that gives women control over their finances (Ndiaye, 2013; Suri and Jack, 2016).

\section{Approaches for Scaling up Gender Equality in CRA}

The IFAD model for scaling up gender equality results (IFAD, 2015) provides a set of approaches and key leverage points for scaling of gender-and socially-inclusive climate-resilient agriculture. Its "innovative approaches" for scaling gender equality include participatory approaches, integrating gender into policy at different levels, promoting decision making and leadership in different contexts and activities, and working through collective action and women's organizations (see Box 1).

Women's collective action and participation in community organizations are important strategies for empowerment, when based in existing community formal or informal networks that are sustainable and socially embedded. Participation in collective action can lead to increased voice and agency as well as increased access to and control of resources. Women's organizations and community groups can be platforms for, as well as enablers of, capacity development and empowerment for women. They do this by providing opportunities to share experiences and promoting collective action in revolving credit, improved production or processing, entrepreneurship, or information provision. They can act as mechanisms to magnify women's voice and shift the way they think of themselves and their entitlements, increasing their negotiating power in communities

\footnotetext{
${ }^{3}$ https://www.ifad.org/documents/38714170/39148759/Ghana+making+value+ chains.pdf/360db056-8215-42c6-b7ed-c05fe298cfc8
}

BOX 1 | IFAD's innovative approaches for scaling gender equality and women's empowerment.

- Participatory, community-based approaches to ensure that the voices of different segments of the rural population-men, women, young people, indigenous people, the poor, and the better-off-are equally heard and valued;

- Embedding gender-sensitive approaches in broader development goals and poverty reduction programs to get greater buy-in from governments and the broader development community;

- Demand-driven approaches for the promotion of pro-poor, gendersensitive innovations to ensure successful uptake, and sustainability;

- Strengthening women's social capital through forming women-only groups and empowering them to access and manage key resources and assets;

- Empowering rural women by transferring to them the decision-making power over the use of funds (such as community development funds) and selection of service providers;

- Promoting participatory infrastructure development to reduce women's workload;

- Reinforcing rural women's self-confidence, knowledge, and skillsincluding technical, leadership, and managerial - through gender-sensitive extension and business advisory services, vocational training, functional literacy, and adoption of appropriate learning approaches (e.g., peer learning, exchange visits, learning routes);

- Engaging with all family members, thus leveraging the positive complementarities between women and men, young and old, to challenge unequal intra-household relations and labor distribution, and promote equitable sharing of resources, income, and workload;

- Fostering women's participation and leadership in farmer and producer organizations and other decision-making bodies through the establishment of quotas and gender-sensitive organizational development;

- Working with government institutions to create an enabling policy, institutional, and cultural environment in support of gender equality and women's empowerment;

- Supporting gender-sensitive project design and implementation through the use of appropriate tools, including setting targets and using checklists for gender-focused poverty and livelihoods analysis.

- Source: (IFAD, 2015).

and households (Datta et al., 2012; Lecoutere, 2017; Mello and Schmink, 2017; Kumar et al., 2018; Huyer et al., 2021). When their role in disseminating change and innovation is incorporated into this function of collective action, they can be a platform for gender and socially inclusive scaling among members, and through connected networks of organizations.

Community and national women's networks have served as platforms to support the scaling up of women's rights and empowerment in different aspects of agriculture. For example:

- Rwanda's Women Network supported paralegals to help women enforce and claim their land rights at the community level, by lodging appeals in higher courts and drafting wills for them. Community-based women's committees can be enabled to take on the legal requirements relating to women's access to credit, in terms of public agro-credit and ability to approach government or public offices (Elbehri and Lee, 2011).

- A collective action and technology training approach in the village of Daga-Birame in Senegal supported women's increased resilience through NTFPs. Processing NTFP, one of the traditional activities led by women in West Africa, has become a significant means of income-generation for women 
to make up for decreasing agricultural production resulting from climate change. The project combined increased agricultural production with participation in community management of natural resources. Activities included: (i) planting fruit trees for improved vegetation cover and income generation, (ii) gardening to increase nutrition and market sales, and (iii) processing of non-timber forest products (NTFP) (baobob). Their involvement in the demonstration trials meant that women in the community were trained in tree planting and grafting. They now grow baobob trees on their own plots and use the fruit, leaves, and wood for household purposes. A mixed-gender committee, also set up by the IP, is responsible for managing community protected areas, including protection of trees in the field and forest, as well as making decisions on when to harvest fruit. Marketing and income management are carried out exclusively through the women's microenterprise. A village savings pool is used to invest in community resilience activities. The project contributed to increasing women's access to and control over forest resources, while the women's group controls the funds used for community improvement. As members on the different committees, women participate in decision making on tree management (Ouédraogo et al., 2018).

The intersection of men and masculinities with women's resilience and gender equality is another underlying gender issue that is under-researched in relation to climate-resilient agriculture-although many studies on CSA adoption, for example, carry out sex-disaggregated analyses (see Villanueva et al., 2016). More research is needed on the gendered impacts of climate change on men, as well as their experience of and responses to climate change (see Correia, 2001). The role of men in promoting women's resilience and agency is an important area for research. Participatory, community collective action approaches in the context of climate-resilient agriculture and land use management may be one avenue to address entrenched norms and attitudes. For example, in Nyando, Kenya, Community Based Organizations (CBOs), served as an entry point to test different CSA options and served as platforms for agricultural learning, delivery of farmer advisory services and agricultural inputs, mobilizing financial resources for loans, and mobilizing farm labor especially for the construction of soil and water conservation structures. These institutional platforms were also used for setting up demonstration farms and act as agricultural knowledge hubs. Work with this kind of group enabled men, women and young farmers to build social capital and an asset base, allowing them to respond to climate-related risks and challenges (Recha et al., 2017; Radeny et al., 2018).

\section{CONCLUSION}

The combination of these frameworks-gender inclusion in CRA, the four dimensions of gender equality in CRA, and the IFAD "Innovative Approaches for scaling"-provide pathways for scaling of CRA that promotes equality and empowerment. When integrated into vertical and horizontal scaling mechanisms of policy at local, national, and global levels; transmitting climate information across sectors, regions, and scales; implementing inclusive finance mechanisms and investment incentives to reduce climate risk; and gender- and socially-inclusive collective action for agency and empowerment in rural areas, a set of pathways for scaling of different CRA dimensions can be developed that will be more inclusive and therefore more effective in scaling CRA approaches. This approach can begin to identify the platforms and mechanisms needed to bridge the gap between the wider approaches required to scale innovative CRA with the participatory approaches that address the priorities and needs of different groups in society.

The IPCC fifth Report notes that "understanding future vulnerability, exposure, and response capacity of interlinked human and natural systems is challenging (IPCC, 2014, p. 11)" as a result of lack of knowledge about the impacts of interacting social, economic, and cultural factors on physical systems. We will need answers to the question of what "strategies and actions can increase resilience... while helping to improve human health, livelihoods and social and economic wellbeing (IPCC, 2014, p. 25)." More research is needed on the approaches, platforms, and mechanisms to promote gender equality and social inclusion in different contexts. What are the influences of gender norms and institutional practices that constrain equality, and what regional differences apply? Can women's collective action around climateresilient agriculture and land use management be a mechanism for scaling up successful equality approaches? What are men's roles in promoting gender equality or avoiding the entrenchment of gender roles? Looking ahead, how do we support improved livelihoods, well-being and empowerment for both women and men? We will need answers to these questions if we are to reach global development and climate targets.

\section{DATA AVAILABILITY STATEMENT}

The original contributions presented in the study are included in the article/supplementary material, further inquiries can be directed to the corresponding author/s.

\section{AUTHOR CONTRIBUTIONS}

All authors listed have made a substantial, direct, and intellectual contribution to the work and approved it for publication.

\section{FUNDING}

This work was implemented as part of the CGIAR Research Program on Climate Change, Agriculture and Food Security (CCAFS), which is carried out with support from CGIAR Trust Fund and through bilateral funding agreements. For details please visit https://ccafs.cgiar.org/donors. The views expressed in this document cannot be taken to reflect the official opinions of these organizations.

\section{ACKNOWLEDGMENTS}

We acknowledge the funding from the International Development Association (IDA) of the World Bank to the Accelerating Impact of CGIAR Climate Research for Africa (AICCRA) project. 


\section{REFERENCES}

Acosta, M., van Wessel, M., van Bommel, S., Ampaire, E. L., Twyman, J., Jassogne, L., et al. (2020). What does it mean to make a 'joint' decision? Unpacking intrahousehold decision making in agriculture: implications for policy and practice. J. Dev. Stud. 56, 1210-1229. doi: 10.1080/00220388.2019.1650169

Agarwal, B. (2010). Gender and Green Governance: The Political Economy of Women's Presence Within and Beyond Community Forestry. Oxford: Oxford University Press. doi: 10.1093/acprof:oso/9780199569687.001.0001

Aggarwal, P. K., Jarvis, A., Campbell, B. M., Zougmoré, R. B., Khatri-chhetri, A., Vermeulen, S. J., et al. (2018). The climate-smart village approach: framework of an integrative strategy. Ecol. Soc. 23, 14.

Aguilar, L., Gilligan, M., Owren, K., Prebble, M., and Westerman, K. (2015). Women in Environmental Decision Making: Case Studies in Ecuador, Liberia, and the Philippines. Washington, DC: IUCN.

Agwu, J., and Okhimamwe, M. (2009). Gender and Climate Change in Nigeria. Lagos: Heinrich Böll Stiftung (HBS).

Akter, S., Krupnik, T. J., Rossi, F., and Khanam, F. (2016). The influence of gender and product design on farmers' preferences for weather-indexed crop insurance. Glob. Environ. Change 38, 217-229. doi: 10.1016/j.gloenvcha.2016.03.010

Alao, T. B., Bamire, A. S., and Kehinde, A. D. (2020). Gender analysis of agricultural financing in cocoa-based farming system in Oyo and Osun States of South Western Nigeria. Ghana J. Agric. Sci. 55, 34-42. doi: 10.4314/gjas.v55i1.4

Ampaire, E. L., Acosta, M., Huyer, S., Kigonya, R., Muchunguzi, P., Muna, R., et al. (2020). Gender in climate change, agriculture, and natural resource policies: insights from East Africa. Clim. Change 158, 43-60. doi: 10.1007/s10584-019-02447-0

Amsler, K., Hein, C., and Klasek, G. (2017). Youth decision making in agricultural climate change adaptations: research findings from East Africa. Copenhagen: CGIAR Research Program on Climate Change, Agriculture and Food Security (CCAFS). Available online at: http://hdl.handle.net/10568/80891 (accessed November 22, 2021).

Ashby, J., Kristjanson, P., Thornton, P., Campbell, B., Vermeulen, S., and Wollenberg, E. (2012). CCAFS Gender Strategy. Copenhagen: CGIAR Climate Change, Agriculture and Food Security Programme.

Assan, E., Suvedi, M., Schmitt Olabisi, L., and Allen, A. (2018). Coping with and adapting to climate change: a gender perspective from smallholder farming in Ghana. Environments 5, 86. doi: 10.3390/environments5080086

Atmadja, S., Lestari, H., Djoudi, H., Liswanti, N., and and, A., Tamara (2020). Making Climate Finance Work for Women and the Poor: Insights from National Climate Finance Mechanisms in Indonesia. Bogor: Center for International Forestry Research.

Bannor, R. K., Oppong-Kyeremeh, H., Derkyi, M., Adombila, A. Y., and Amrago, E. Y. (2020). Village savings and loans association participation and impact on off-farm income among rural women. J. Enterpr. Commun. People Places Glob. Econ. 14, 539-562. doi: 10.1108/JEC-04-2020-0058

Bastakoti, G. B., and Doneys, P. (2020). Gendered perceptions of climate variability, food insecurity, and adaptation practices in Nepal. Clim. Dev. 12, 547-563. doi: 10.1080/17565529.2019.1660604

Batliwala, S. (1994). “The meaning of women's empowerment: new concepts from action," in Population Policies Reconsidered: Health, Empowerment, and Rights, eds G. Sen, A. Germain, and L. C. Chen (Boston, MA: Harvard Center for Population and Development Studies), 127-138.

Bayala, J., Zougmoré, R., Ky-Dembele, C., Bationo, B. A., Buah, S., Sanogo, D., et al. (2016). Towards Developing Scalable Climate-Smart Village Models: Approach and Lessons Learnt from Pilot Research in West Africa. 25. ICRAF Occasional Paper. Nairobi: World Agroforestry Centre.

Borgonovi, F., Centurelli, R., Dernis, H., Grundke, R., Horvát, P., Jamet, S., et al. (2018). Bridging the Digital Gender Divide. OECD. 1-151. Availabel online at: https://www.google.com/search?q=organisation+for+economic+ co-operation + and + development $+($ oecd $)+$ countries\&rlz $=1 \mathrm{C} 1 \mathrm{GCEU}$ enZA825ZA825\&oq=Organisation + for + Economic + Co-operation + and + Development $+\&$ aqs $=$ chrome.2.69i57j014j46j012.16632j0j7\&sourceid= chrome\&ie=UTF- 8 (accessed November 22, 2021).

Bullock, R., Huyer, S., Shai, T., and Nyasimi, M. (2020). The CCAFS Youth and Climate-Smart Agriculture (CSA) Strategy. Wageningen: CGIAR Research Program on Climate Change, Agriculture and Food Security (CCAFS).
Carr, E. R., Fleming, G., and Kalala, T. (2016). Understanding women's needs for weather and climate information in agrarian settings: the case of Ngetou Maleck, Senegal. Weath. Clim. Soc. 8, 247-264. doi: 10.1175/WCAS-D-15-0075.1

Carr, M., and Hartl, M. (2010). Lightening the Load. Rome: IFAD. doi: $10.3362 / 9781780440620$

CCAFS. (2016). CGIAR Research Program on Climate Change, Agriculture and Food Security: Full Proposal 2017-2022. Copenhagen: CGIAR Research Program on Climate Change, Agriculture and Food Security (CCAFS).

Chanana, N., Khatri-chhetri, A., Pande, K., and Joshi, R. (2018). Integrating Gender into the Climate-Smart Village Approach of Scaling out Adaptation Options in Agriculture. CCAFS Info Note. CGIAR Research Program on Climate Change, Agriculture and Food Security (CCAFS).

Chanana-Nag, N., and Aggarwal, P. K. (2018). Woman in agriculture, and climate risks: hotspots for development. Clim. Change. 158, 13-27. doi: 10.1007/s10584-018-2233-z

Chandra, A., McNamara, K., E., and Dargusch, P. (2017). The relevance of political ecology perspectives for smallholder climate-smart agriculture: a review. J. Polit. Ecol. 24, 821-842. doi: 10.2458/v24i1.20969

Chen, M. A. (1995). Engendering World Conferences: The International Women's Movement and the United Nations. Third World Q. 16, 477-494. doi: $10.1080 / 01436599550036013$

Chi, T. T. N., Paris, T., Le Duy, T. T. T. A., and Loan, D. T. (2015). Enhancing the Roles of Women in Rice Farming as an Adaptation Strategy to Climate Change Risks : A Case Study in Submergence Villages in Hau Giang Province, South Vietnam. Hanoi: Cuu Long Rice Institute.

Chingarande, D., Huyer, S., Lanzarini, S., Makokha, J. N., Masiko, W., Mungai, C., et al. (2020). Background Paper on Mainstreaming Gender into National Adaption Planning and Implementation in Sub-Saharan Africa. Wageningen: CGIAR Research Program on Climate Change, Agriculture and Food Security (CCAFS).

Correia, M. (2001). Hurricane Mitch - the Gender Effects of Coping and Crises. Washington, DC: World Bank.

Cramer, L., Förch, W., Mutie, I., and Thornton, P. K. (2016). Connecting women, connecting men: how communities and organizations interact to strengthen adaptive capacity and food security in the face of climate change. Gend. Technol. Dev. 20, 169-199. doi: 10.1177/0971852416639771

Croppenstedt, A., Goldstein, M., and Rosas, N. (2013). Gender and agriculture: inefficiencies, segregation, and low productivity traps. World Bank Res. Obser. 28, 79-109. doi: 10.1093/wbro/lks024

Datta, D., Chattopadhyay, R. N., and Guha, P. (2012). Community based mangrove management: a review on status and sustainability. J. Environ. Manage. 107, 84-95. doi: 10.1016/j.jenvman.2012.04.013

Delavallade, C., Dizon, F., Vargas Hill, R., and Petraud, J. P. (2015). Managing Risk with Insurance and Savings: Experimental Evidence for Male and Female Farm Managers in West Africa. Washington, DC: IFPRI. doi: 10.2139/ssrn.2583847

Dembele, D., and Samuel., S. (March 3, 2019). To celebrate Africa environment day, CCAFS showcases its efforts to mainstream gender equality into climatesmart agriculture in Ethiopia, Mali, Rwanda and Senegal. CCAFS News. Wageningen: CCAFS.

Demirguc-Kunt, A., Klapper, L., Singer, D., Ansar, S., and Hess, J. (2018). The Global Findex Database 2017: Measuring Financial Inclusion and the Fintech Revolution. Washington DC: World Bank. doi: 10.1596/978-1-4648-1259-0

Diouf, D. S., Ouedraogo, M., Ouedraogo, I., Ablouka, G., and Zougmoré R. (2020). Using seasonal forecast as an adaptation strategy: gender differential impact on yield and income in Senegal. Atmosphere 11, 1-19. doi: 10.3390/atmos11101127

Domingo, P., Holmes, P., O’Neil, T., Jones, N., Bird, K., Larson, A., et al. (2015). Women's Voice and Leadership in Decision-Making: Assessing the Evidence. London: Overseas Development Institute.

Duong, M. T., Simelton, E., and Le, V. H. (2016). Participatory Identification of Climate-Smart Agriculture Priorities. Copenhagen: CGIAR Climate Change, Agriculture and Food Security Program.

Duong, T. N., Smith, A., Le, T. T., Simelton, E., and Coulier, M. (2017). Gender-Differences in Agro-Climate Information Services. Copenhagen: CGIAR Research Program on Climate Change, Agriculture and Food Security (CCAFS).

Eeswaran, R., Nejadhashemi, A. P., and Miller, S. R. (2021). Evaluating the climate resilience in terms of profitability and risk for a long-term corn-soybean-wheat 
rotation under different treatment systems. Climate Risk Management 32, 100284. doi: 10.1016/j.crm.2021.100284

Elbehri, A., and Lee, M. (2011). The Role of Women Producer Organizations in Agricultural Value Chains: Practical Lessons from India and Africa. Rome: FAO.

FAO, IFAD, UNICEF, WFP, and WHO. (2018). The State of Food Security and Nutrition in the World 2018. Rome: FAO.

FAO. (2011). The State of Food and Agriculture 2010-2011: Women in Agriculture - Closing the Gender Gap for Development. Rome: Food and Agriculture Organization. Available online at: http://www.fao.org/3/i2050e/i2050e.pdf

FAO. (2013). Good Practice Policies to Eliminate Gender Inequalities in Fish Value Chains. Rome: FAO.

FAO. (2014). The State of Food Inseurity in the World (SOFI). Rome: FAO.

FAO. (2016). Gender, Food Security and Nutrition in Protracted Crises. Rome: FAO.

FAO. (2017). The Future of Food and Agriculture - Trends and Challenges. Rome: FAO.

FAO. (2018). Leaving No One behind: Empowering Africa's Rural Women for Zero Hunger and Shared Prosperity. Rome: FAO.

Farnworth, C. R., Ha, T. T., Sander, B. O., Wollenberg, E., De Haan, N. C., and McGuire, S. (2017). Incorporating gender into low-emission development: a case study from Vietnam. Gender Technol. Dev. 21, 5-30. doi: 10.1080/09718524.2017.1385314

Federal Republic of Nigeria. (2020). National Action Plan on Gender and Climate Change. Abuja: Federal Republic of Nigeria.

Fisher, M., and Carr, E. R. (2015). The influence of gendered roles and responsibilities on the adoption of technologies that mitigate drought risk: the case of drought-tolerant maize seed in Eastern Uganda. Glob. Environ. Change 35, 82-92. doi: 10.1016/j.gloenvcha.2015. 08.009

Fortnam, M., Brown, K., Chaigneau, T., Crona, B., Daw, T. M., Gonçalves, D., et al. (2019). The gendered nature of ecosystem services. Ecol. Econ. 159, 312-325. doi: 10.1016/j.ecolecon.2018.12.018

Gonda, N. (2016). Climate change, 'technology' and gender: 'adapting women' to climate change with cooking stoves and water reservoirs. Gend. Technol. Dev. 20, 149-168. doi: 10.1177/0971852416639786

Greatrex, H., Hansen, J., Garvin, S., Diro, R., Blakeley, S., Le Guen, M., et al. (2015). Scaling Up Index Insurance for Smallholder Farmers: Recent Evidence and Insights. CCAFS Report. Copenhagen, Denmark: CGIAR Research Program on Climate Change, Agriculture and Food Security (CCAFS).

GSMA (2012). Striving and Surviving: Exploring the Lives of Women at the Base of the Pyramid. GSMA Women Programme. London: GSMA. Available online at: https://www.gsma.com/mobilefordevelopment/resources/strivingsurviving-exploring-the-lives-of-women-at-the-base- of-the-pyramid/ (accessed November 22, 2021).

GSMA (2020). The Mobile Economy 2020. London: GSM Association. https:// www.gsma.com/mobileeconomy/wp-content/uploads/2020/2003/GSMA_ MobileEconomy2020_Global.pdf

GSMA Connected Women (2015). Bridging the Gender Gap: Mobile Access and Usage in Low- and Middle-Income Countries. London: GSMA Connected Women.

Gumucio, T., Hansen, J., Huyer, S., and van Huysen, T. (2020). Gender-responsive rural climate services: a review of the literature. Clim. Dev. 12, 241-254. doi: 10.1080/17565529.2019.1613216

Gumucio, T., and Rueda, M. T. (2015). Influencing gender-inclusive climate change policies in Latin America. J. Gend. Agric. Food Secur. 1, 42-61. doi: 10.22004/AG.ECON.246049

Hariharan, V. K., Mittal, S., Rai, M., Agarwal, T., Kalvaniya, K. C., Stirling, C. M., et al. (2020). Does climate-smart village approach influence gender equality in farming households? A case of two contrasting ecologies in India. Clim. Change 158, 77-90. doi: 10.1007/s10584-018-2321-0

Hernandez, E., Humam, Y., Ciacci, R., Benni, N., and Kaaria,. S. (2018). Female smallholders in the financial inclusion Agenda. CGAP Brief. Washington, DC: CGAP. doi: 10.1596/30109

Huyer, S. (2016). Closing the gender gap in agriculture. Gend. Technol. Dev. 20, 105-116. doi: 10.1177/0971852416643872

Huyer, S. (2019). "ICT in a changing climate: a path to gender-transformative food security," in Taking Stock: Data and Evidence on Gender Digital Equality, eds A. Sey and N. Hafkin. Macau: United Nations University. Available online at: https://i.unu.edu/media/cs.unu.edu/attachment/4040/EQUALS-ResearchReport-2019.pdf (accessed November 22, 2021).

Huyer, S., Acosta, M., Gumucio, T., and Ilham, J. I. J. (2020). Can we turn the tide? Confronting gender inequality in climate policy. Gend. Dev. 28, 571-591. doi: 10.1080/13552074.2020.1836817

Huyer, S., Gumucio, T., Tavenner, K., Acosta, M., Chanana, N., Khatri-Chhetri, A., et al. (2021). "From vulnerability to agency: gender equality in climate adaptation and mitigation," in Advancing Gender Equality through Agricultural and Environmental Research: Past, Present and Future, eds R. Pyburn and A. van Eerdewijk (Washington, DC: IFPRI), 222-256.

Huyer, S., and Partey, S. (2020). Weathering the storm or storming the norms? Moving gender equality forward in climate-resilient agriculture. Clim. Change 158, 1-12. doi: 10.1007/s10584-019-02612-5

Huyer, S., Twyman, J., Koningstein, M., Ashby, J., and Vermeulen, S. J. (2015). Supporting Women Farmers in a Changing Climate: Five Policy Lessons. Copenhagen: CGIAR Climate Change, Agriculture and Food Security Programme. Available online at: https://cgspace.cgiar.org/rest/bitstreams/ $60479 /$ retrieve

IFAD (2015). Gender Equality and Women's Empowerment: Scaling up Note. Rome: IFAD.

ILO (2020). Global Employment Trends for Youth. Geneva: ILO.

IPCC (2014). "Summary for policy makers," in Climate Change 2014: Impacts, Adaptation and Vulnerability - Contributions of the Working Group II to the Fifth Assessment Report, eds C. B. Field, V. R. Barros, D. J. Dokken, K. J. Mach, M. D. Mastrandrea, T. E. Bilir, M. Chatterjee, K. L. Ebi, Y. O. Estrada, R. C. Genova, B. Girma, E. S. Kissel, A. N. Levy, S. MacCracken, P. R. Mastrandrea, and L. L.White (Cambridge; New York, NY: IPCC), 1-32. doi: 10.1016/j.renene.2009.11.012

IPU (2021). Women in Parliament: 2021. Geneva: Inter-Parliamentary Union. Available online at: https://www.ipu.org/women-in-politics-2021

IUCN (2011). Draft Guidelines to Mainstreaming Gender in the Development of National Adaptation Plans (NAPs). IUCN.

Jacobs, F., Ubels, J., and Woltering, L. (2018). The Scaling Scan - A Practical Tool to Determine the Strengths and Weaknesses of Your Scaling Ambition. Rotterdam; Texcoco: PPPLab and CIMMYT.

Jost, C., Kyazze, F., Naab, J., Neelormi, S., Kinyangi, J., Zougmore, R., et al. (2016). Understanding gender dimensions of agriculture and climate change in smallholder farming communities. Clim. Dev. 8, 1-12. doi: 10.1080/17565529.2015.1050978

Kabeer, N. (1999). Resources, agency, achievements: reflections on the measurement of women's empowerment. Dev. Change 30, 435-464. doi: 10.1111/1467-7660.00125

Kantor, P., Morgan, M., and Choudhury, A. (2015). Amplifying outcomes by addressing inequality: the role of gender-transformative approaches in agricultural research for development. Gend. Technol. Dev. 19, 292-319. doi: $10.1177 / 0971852415596863$

Kassam, A., Friedrich, T., Shaxson, F., and Pretty, J. (2009). The spread of conservation agriculture: justification, sustainability and uptake. Int. J. Agric. Sustain. 7, 292-320. doi: 10.3763/ijas.2009.0477

Khatri-Chhetri, A., Regmi, P. P., Chanana, N., and Aggarwal, P. K. (2020). Potential of climate-smart agriculture in reducing women farmers' drudgery in high climatic risk areas. Clim. Change 158, 29-42. doi: 10.1007/s10584-018-2350-8

Krell, N. T., Giroux, S. A., Guido, Z., Hannah, C., Lopus, S. E., Caylor, K. K., et al. (2020). Smallholder farmers' use of mobile phone services in Central Kenya. Clim. Dev. 13, 215-227. doi: 10.1080/17565529.2020.174 8847

Kristjanson, P., Bryan, D., Bernier, Q., Twyman, J., Meinzen-Dick, R., Kieran, C., et al. (2017). Addressing gender in agricultural research for development in the face of a changing climate: where are we and where should we be going? Int. J. Agric. Sustain. 15, 482-500. doi: 10.1080/14735903.2017.1336411

Kristjanson, P., Waters-Bayer, A., Johnson, N., Tipilda, A., Njuki, J., Baltenweck, G. D., et al. (2014). "Livestock and women's livelihoods: a review of the recent evidence," in Gender in Agriculture and Food Security: Closing the Knowledge Gap, eds A. Quisumbing, R. Meinzen-Dick, T. Raney, A. Croppensteadt, J. A. Behrman, and A. Peterman et al. (Dordrecht: Springer), 209-233. doi: 10.1007/978-94-017-8616-4_9 
Krizsan, A., and Lombardo, E. (2013). The Quality of gender equality policies: a discursive approach. Eur. J. Womens Stud. 20, 77-92. doi: $10.1177 / 1350506812456462$

Ksoll, C., Lilleør, H., B., Lønborg, J., H., Rasmussen, O., et al. (2016). Impact of village savings and loan associations: evidence from a cluster randomized trial. J. Dev. Econ. 120, 70-85. doi: 10.1016/j.jdeveco.2015.12.003

Kumar, N., Scott, S., Menon, P., Kannan, S., Cunningham, K., Tyagi, P., et al. (2018). Pathways from women's group-based programs to nutrition change in South Asia: a conceptual framework and literature review. Glob. Food Secur. 17, 172-185. doi: 10.1016/j.gfs.2017.11.002

Lecoutere, E. (2017). The impact of agricultural co-operatives on women's empowerment: evidence from Uganda. J. Cooperat. Organ. Manage. 5, 14-27. doi: 10.1016/j.jcom.2017.03.001

Lipper, L., Thornton, P., Campbell, B. M., Baedeker, T., Braimoh, A., Bwalya, M., et al. (2014). Climate-smart agriculture for food security. Nat. Clim. Chang. 4, 1068-1072. doi: 10.1038/nclimate2437

Luttrell, C., Quiroz, S., Scrutton, C., and Bird, K. (2009), Understanding and Operationalising Empowerment. Working Paper 308. London: Overseas Development Institute.

Manfre, C., Rubin, R., Allen, A., and Summerfield, S. (2013). Reducing the Gender Gap in Agricultural Extension and Advisory Services. Washington, DC: USAID.

Manlosa, A. O., Schultner, J., Dorresteijn, S., and Fischer, J. (2019). Leverage points for improving gender equality and human well-being in a smallholder farming context. Sustain. Sci. 14, 529-541. doi: 10.1007/s11625-018-0636-4

Mansuri, G., and Rao, V. (2012). Localizing Development: Does Participation Work? Washington, DC: World Bank. doi: 10.1596/978-0-8213-8256-1

Martin, B. L., and Abbott, E. (2011). Mobile phones and rural livelihoods: diffusion, uses, and perceived impacts among farmers in rural Uganda. Inform. Technol. Int. Dev. 7, 17-34.

Mcleod, E., Arora-Jonsson, S., Masuda, Y. J., Bruton-Adams, M., Emaurois, C. O., Gorong, B., et al. (2018). Raising the voices of pacific island women to inform climate adaptation policies. Mar. Policy 93, 178-185. doi: 10.1016/j.marpol.2018.03.011

Mello, D., and Schmink, M. (2017). Amazon entrepreneurs: women's economic empowerment and the potential for more sustainable land use practices. Womens Stud. Int. Forum 65, 28-36. doi: 10.1016/j.wsif.2016.11.008

Mittal, S. (2016). Role of mobile phone-enabled climate information services in gender-inclusive agriculture. Gend. Technol. Dev. 20, 200-217. doi: $10.1177 / 0971852416639772$

Mudege, N. N., Mdege, N., Abidin, P. E., and Bhatasara, S. (2017). The role of gender norms in access to agricultural training in Chikwawa and Phalombe, Malawi. Gend. Place Cult. 24, 1689-1710. doi: 10.1080/0966369X.2017.1383363

Mulema, A., Cramer, L., and Huyer, S. (2021). Stakeholder Engagement in Gender and Climate Change Policy Processes: Lessons from CCAFS. Wageningen: CGIAR Research Program on Climate Change, Agriculture and Food Security (CCAFS).

Mutenje, M. J., Farnworth, C. R., Stirling, C., Thierfelder, C., Mupangwa, W., and Nyagumbo, I. (2019). A cost-benefit analysis of climate-smart agriculture options in southern africa: balancing gender and technology. Ecol. Econ. 163, 126-137. doi: 10.1016/i.ecolecon.2019.05.013

Ndiaye, O. K. (2013). Is the success of M-Pesa empowering kenyan rural women? Feminist Africa No. 18, 156-161. Available online at: http://www.agi.ac.za/ sites/default/files/image_tool/images/429/feminist_africa_journals/archive/18/ standpoints_is_the_success_of_m-pesa_empowering_kenyan_rural_women_. pdf (accessed November 22, 2021).

Office of the Special Advisor on Gender Issues (OSAGI). (2001). Important Concepts underlying Gender Mainstreaming. New York, NY: United Nations.

Ouédraogo, M., Partey, S. T., Zougmoré, R., Derigubah, M., Sanogo, D., Boureima, N., et al. (2018). Mainstreaming Gender and Social Differentiation into CCAFS Research Activities in West Africa: Lessons Learned and Perspectives. Wageningen: CGIAR Research Program on Climate Change, Agriculture and Food Security (CCAFS). Available online at: https://ccafs.cgiar. org/publications/mainstreaming-gender-and-social-differentiation-ccafsresearch-activities-west-africa\#.XdhFgS0ZOu4 (accessed November 22, 2021).

Owombo, P. T., Koledoye, G. F., Ogunjimi, S. I., Akinola, A. A., Deji, O. F., and Bolarinwa, O. (2014). Farmer's adaptation to climate change in Ondo state, Nigeria: a gender analysis. J. Geogr. Reg. Plann. 7, 30-35. doi: $10.5897 / J G R P 12.071$
Partey, S. T., Dakorah, A. D., Zougmoré, R. B., Ouédraogo, M., Nyasimi, M., Nikoi, G. K., et al. (2020). Gender and climate risk management: evidence of climate information use in Ghana. Clim. Change 158, 61-75. doi: 10.1007/s10584-018-2239-6

Perez, C., Jones, E. M., Kristjanson, P., Cramer, L., Thornton, P. K. Förch, W., et al. (2015). How resilient are farming households and communities to a changing climate in africa? A gender-based perspective. Glob. Environ. Change 34, 95-107. doi: 10.1016/j.gloenvcha.2015. 06.003

Porciello, J., Coggins, S., Otunba-Payne, G., Mabaya, E. (2021b). A Systematic Scoping Review: How are farmers using digital services in low- and middleincom countries? Agriculture in the Digital Age. New York, NY: Cornell University, p. 84. Available online at: https://ecommons.cornell.edu/handle/ $1813 / 103771$

Porciello, J., Coggins, S., Otunda-Payne, G., and Mabaya, E. (2021a). How Are Farmers Using Digital Services in Low- and Middle-Income Countries? Bill \& Melinda Gates Foundation USAID.

Radeny, M., Ogada, M. J., Recha, J., Kimeli, P., Rao, E. J. O., and and, Solomon, D. (2018). Uptake and Impact of Climate-Smart Agriculture Technologies and Innovations in East Africa. Wageningen: CGIAR Research Program on Climate Change, Agriculture and Food Security (CCAFS).

Rao, N., Lawson, E., T., Raditloaneng, W., N., Solomon, D., et al. (2019). Gendered vulnerabilities to climate change: insights from the semi-arid regions of Africa and Asia. Clim. Dev. 11, 14-26. doi: 10.1080/17565529.2017.13 72266

Recha, J., Kimeli, P., Atakos, V., Radeny, M., and Mungai, C. (2017). Stories of Success: Climate-Smart Villages in East Africa. Wageningen: CGIAR Research Program on Climate Change, Agriculture and Food Security (CCAFS).

Recha, J., Radeny, M., Kinyangi, J., Kimeli, P., Atakos, V., Lyamchai, C., et al. (2015). Climate-Smart Villages and Progress in Achieving Household Food Security in Lushoto, Tanzania. Copenhagen, Denmark: CGIAR Research Program on Climate Change, Agriculture and Food Security (CCAFS).

Rengalakshmi, R., Manjula, M., and Devaraj, M. (2018). Making climate information communication gender sensitive: lessons from Tamil Nadu. Econ. Polit. Wkly. 53, 87-95.

Resurrección, B. P., Bee, B. A., Dankelman, I., C., Park, M. Y., Halder, M., et al. (2019). Gender-Transformative Climate Change Adaptation: Advancing Social Equity. Background paper to the 2019 report of the Global Commission on Adaptation. Rotterdam; Washington, DC.

Roncoli, C., Jost, C., Kirchen, P., Sanon, M., Ingram, K. T., Woodin, M., et al. (2011). From accessing to assessing forecasts: an end-toend study of participatory climate forecast dissemination in Burkina Faso (West Africa). Clim. Change 92, 433-460. doi: 10.1007/s10584-0089445-6

Schatalek, L., and Nakhooda, S. (2014). Gender and Climate Finance. London; Washington, DC: United Nations Development Programme.

Sekabira, H., and Qaim, M. (2017). Can mobile phones improve gender equality and nutrition? Panel data evidence from farm households in Uganda. Food Policy 73, 95-103. doi: 10.1016/j.foodpol.2017.10.004

Sen, A. K. (1997). From income inequality to economic inequality. South. Econ. J. $64,384-401$.

Shinn, J. E., and Hall-Reinhard, A. (2019). Emphasizing livelihoods in the study of social-ecological systems: insights from fishing practices in the Okavango Delta, Botswana. South Afr. Geograph. J. 101, 121-139. doi: $10.1080 / 03736245.2018 .1562365$

Simelton, E., Duong, T. M., and Houzer, E. (2021a). When the 'strong arms' leave the farms-migration, gender roles and risk reduction in Vietnam. Sustainability 13, 4081. doi: 10.3390/su13074081

Simelton, E., Le, T., Coulier, M., Duong, M., and Le, D. (2018). "Developing participatory agro-climate advisories for integrated and agroforestry systems." in Towards Low-Emissions Landscapes in Viet Nam, eds R. Mulia, and E. Simelton (Bogor: ICRAF) 129-144.

Simelton, E., Mulia, R., Nguyen, T. T., Duong, T. M., Le, H. X., and Tran, L. H. (2021b). Women's Involvement in Coffee Agroforestry Value-Chains: Financial Training, Village Savings and Loans Associations, and Decision Power in Northwest Vietnam. CCAFS Working Paper No. 340. Wageningen: 
CGIAR Research Program on Climate Change, Agriculture and Food Security (CCAFS).

Sioson, E. P., and Kim, C. J. (2019). Closing the Gender Gap in Financial Inclusion through Fintech. Tokyo: ADB Institute.

Sterling, R., and Huyer, S. (2010). 89.1 FM: the place for development: power shifts and participatory spaces in ICTD. J. Commun. Inform. 5, pp. 87-96.

Suri, T., and Jack, W. (2016). The long-run poverty and gender impacts of mobile money. Science 354, 1288-1292. doi: 10.1126/science.aah5309

Tall, A., Kristjanson, P., Chaudhury, M., and Mckune, S. (2014). Who Gets the Information? Gender, Power and Equity Considerations in the Design of Climate Services for Farmers. Copenhagen: CGIAR Climate Change, Agriculture and Food Security Programme.

Tsige, M., Synnevåg, G., and Aune, J. B. (2020). Gendered constraints for adopting climate-smart agriculture amongst smallholder ethiopian women farmers. Scient. Afr. 7:e00250. doi: 10.1016/j.sciaf.2019.e00250

Twyman, J., Green, M., Bernier, Q., Kristjanson, P., Russo, S., Tall, A., et al. (2014). Adaptation Actions in Africa: Evidence That Gender Matters. Copenhagen: CGIAR Climate Change, Agriculture and Food Security Programme. Available online at: https://cgspace.cgiar.org/bitstream/handle/10568/51391/WP83.pdf (accessed November 22, 2021).

UN Women (2020). World's Women 2020. New York, NY: United Nations.

UNCTAD (2011). Information Economy Report 2011: ICTs as an Enabler for Private Sector Development. New York; Geneva: United Nations.

UNCTAD (2020). The Impact of Rapid Technological Change on Sustainable Development. Geneva: UNCTAD. doi: 10.18356/e7663910-en

UNCTAD (2021a). Technology and Innovation Report 2021: Catching Technological Waves, Innovation with Equity. Geneva: UNCTAD.

UNCTAD (2021b). Applying a Gender Lens to Science, Technology and Innovation. Geneva: UNCTAD.

UNDP (2016). Gender Equality in National Climate Action: Planning for Gender-Responsive National Determined Contributions (NDCs). New York: UNDP. Available online at: http://www.undp.org/content/undp/en/home/ librarypage/womens-empowerment/gender-equality-in-national-climateaction--planning-for-gender-.html (accessed November 22, 2021).

United Nations Statistics Division (UNSD) (2020). World's Women 2020. New York, NY: United Nations.

United Nations. (2015). The World's Women 2015. New York, NY: United Nations, Department of Economic and Social Affairs, Statistics Division.

van Aelst, K., and Holvoet, N. (2018). Climate change adaptation in the Morogoro region of Tanzania: women's decision-making participation in small-scale farm households. Clim. Dev. 10, 495-508. doi: 10.1080/17565529.2017.1318745

van Eerdewijk, A., Wong, F., Vaast, C., Newton, J., Tyszler, M., and Pennington, A. (2017). A Conceptual Model of Women and Girls' Empowerment. Amsterdam: Royal Tropical Institute (KIT). Available online at: https:// 213ou636sh0ptphd141fqeil-wpengine.netdna-ssl.com/gender/wp-content/ uploads/sites/3/2017/03/BMGF_KIT_WhitePaper_web-1.pdf (accessed November 22, 2021).

Venkatasubramanian, K., Tall, A., Hansen, H., and Aggarwal, P. (2014). Assessment of India's Integrated Agro-Meteorological Advisory Service from a Farmer Perspective. Copenhagen: CGIAR Research Program on Climate Change, Agriculture and Food Security (CCAFS).

Vermeulen, S. (2015). Closing the Gender Gap in Climate-Smart Agriculture A Brief Review of Recent Approaches Relevant to CSA Programs. Copenhagen: CGIAR Climate Change, Agriculture and Food Security Programme.
Vernooy, R., and Bouroncle, C. (2019). Climate-Smart Agriculture: in Need of a Theory of Scaling. CGIAR Research Program on Climate Change, Agriculture and Food Security (CCAFS). Wageningen, the Netherlands. Available online at: https://hdl.handle.net/10568/99822 (accessed November 22, 2021).

Villanueva, A. B., Jha, Y., Ogwal-omara, R., Welch, E., Wedajoo, S., and Halewood, M. (2016). Influence of Social Networks on the Adoption of Climate Smart Technologies in East Africa Findings from Two Surveys and Participatory Exercises with Farmers and Local Experts. Copenhagen: CGIAR Research Program on Climate Change, Agriculture and Food Security (CCAFS).

WEDO. (2020). UNFCCC: Progress on Achieving Gender Balance. New York, NY.

Westermann, O., Thornton, P., and Förch, W. (2015). Reaching More Farmers - Innovative Approaches to Scaling up Climate Smart Agriculture. CCAFS Working Paper no. 135. Copenhagen: CCAFS.

Wong, S. A. M. (2016). Can climate finance contribute to gender equity in developing countries? J. Int. Dev. 28, 428-444. doi: 10.1002/jid.3212

World Bank, FAO, and IFAD. (2015). Gender in Climate-Smart Agriculture. Washington DC: World Bank, FAO, IFAD. Available online at: http:// documents.worldbank.org/curated/en/654451468190785156/pdf/99505REVISED-Box393228B-PUBLIC-Gender-and-Climate-Smart-AG-WEB-3. pdf (accessed November 22, 2021).

World Bank. (2013). Inclusion Matters: The Foundation for Shared Prosperity. Washington DC: The World Bank. doi: 10.1596/9781464800108

World Food Programme (WFP) and Oxfam America (2018). R4 Rural Resilience Initiative. Annual Report. Rome: World Food Program. World Food Programme (WFP), and Oxfam America.

Wyche, S., and Olson, J. (2018). Kenyan women's rural realities, mobile internet access, and 'Africa rising.' Inf. Technol. Int. Dev. 14, 33-47.

Yang, Y. C. E., Passarelli, S., Lovell, R. J., and Ringler, C. (2018). Gendered perspectives of ecosystem services: a systematic review. Ecosyst. Serv. 31, 58-67. doi: 10.1016/j.ecoser.2018.03.015

Zougmoré, R. B., Partey, S. T., Totin, E., Ouédraogo, M., Thornton, P., Karbo, N., et al. (2019). Science-policy interfaces for sustainable climate-smart agriculture uptake: lessons learnt from national science-policy dialogue platforms in West Africa. Int. J. Agric. Sustain. 17, 367-382. doi: 10.1080/14735903.2019.1670934

Conflict of Interest: The authors declare that the research was conducted in the absence of any commercial or financial relationships that could be construed as a potential conflict of interest.

Publisher's Note: All claims expressed in this article are solely those of the authors and do not necessarily represent those of their affiliated organizations, or those of the publisher, the editors and the reviewers. Any product that may be evaluated in this article, or claim that may be made by its manufacturer, is not guaranteed or endorsed by the publisher.

Copyright (c) 2021 Huyer, Simelton, Chanana, Mulema and Marty. This is an openaccess article distributed under the terms of the Creative Commons Attribution License (CC BY). The use, distribution or reproduction in other forums is permitted, provided the original author(s) and the copyright owner(s) are credited and that the original publication in this journal is cited, in accordance with accepted academic practice. No use, distribution or reproduction is permitted which does not comply with these terms. 